\title{
The beginning of herding and animal management: the early development of caprine herding on the Konya plain, central Anatolia
}

\author{
Caroline Middleton \\ University of Liverpool, UK \\ caro.middleton@me.com
}

\begin{abstract}
Little is known about the initial appearance of herding in central Anatolia. Although morphologically domestic caprines are present from the foundation of Çatalhöyük East, ca 7,100 cal. BC, how and when domestic caprines became an integral part of the central Anatolian economy, and their status and relationship with earlier communities, is unclear. This article reports the results of a study in which carbon and nitrogen stable isotopes were used to provide signatures of caprine diet and thus pasturing practices; as an animal's movements are affected by human intervention, changes in animal diets should be visible through changes in $\delta^{15} \mathrm{~N}$ and $\delta^{13} \mathrm{C}$ levels. A sequence of seven sites on the Konya plain, covering the period ca 9,000-4,500 cal. BC, provided bone samples for carbon and nitrogen analysis. An unaffected local dietary signature for caprines was created using the fauna from Epipalaeolithic Pınarbaş and a $\mathrm{C}_{3} / \mathrm{C}_{4}$ plant baseline. This dietary signature, along with dietary information from the domesticated caprines at later sites, allowed changes in diet resulting from human intervention to be mapped. Changes in diet are found to have occurred at sites where there is no morphometric or demographic data suggestive of early herding or domesticates. This new dietary data extends our knowledge and understanding of how and when caprines and cattle came under human control on the Konya plain, central Anatolia.
\end{abstract}

\section{Özet}

Orta Anadolu'da hayvancılığın ilk ortaya çıkıșı hakkında çok az şey bilinmektedir. Morfolojik olarak yerli keçiler, Çatalhöyük Doğu Höyüğü’nün kuruluşundan, yani yaklaşık M.Ö. 7100 cal. tarihinden beri mevcut olmasına rağmen, yerli keçilerin nasıl ve ne zaman Orta Anadolu ekonomisinin ayrılmaz bir parçası haline geldiği, konumları ve önceki topluluklarla olan ilişkileri belirsizdir. Bu makalede, karbon ve nitrojen stabil izotoplarının, keçilerin beslenme biçimini ve böylece otlatma uygulamalarını göstermek için kullanıldığı bir çalışmanın sonuçları rapor edilmiştir. Hayvan hareketlerinin insan müdahalesinden etkilenmesinden dolayı, hayvan yemlerinde meydana gelen değişiklikler $\delta^{15} \mathrm{~N}$ ve $\delta^{13} \mathrm{C}$ tabakalarındaki değişiklikler yoluyla gözlenmiştir. Konya ovasında bulunan ve yaklaşık olarak M.Ö. 9000-4500 cal. tarihini kapsayan yedi tane yerleşimden karbon ve nitrojen analizleri için kemik örnekler ele geçmiştir. Keçiler için doğal (etkiye uğramamış) yerli beslenme şekli, Epipaleolitik dönem Pınarbaşı'nın faunasından ve C3/C4 bitki tabanından sağlanmıştır. Beslenmeye dair bu işaret, daha sonraki dönemlere ait yerleşimlerdeki evcilleştirilmiş keçilerden elde edilen bilgilerle birlikte, insan müdahalesinden kaynaklanan beslenme değişikliklerini saptamaya izin vermektedir. Beslenmedeki değişikliklerin, erken dönem hayvancılığı veya evcilleştirmeyi gösteren morfometrik veya demografik verilere sahip olmayan yerleşimlerde meydana geldiği tespit edilmiştir. Beslenmeyle ilgili bu yeni veriler, orta Anadolu'da yer alan Konya ovasındaki keçi ve sığırların insan kontrolü altına ne zaman ve nasıl girdiği konusundaki bilgi ve anlayışımızı geliştirmektedir.

\begin{abstract}
A lthough the domestication of animals has had a profound effect on our species, the identification of the earliest herded animals and domesticates remains difficult. Identifying human intervention in animal behaviour prior to the appearance of morphologically iden-
\end{abstract}

tifiable domesticates is an ongoing challenge. Established zooarchaeological methodologies, for example morphological changes indicative of domestication, involve a time lag between initial management and the morphometric changes that signify domesticates (Zeder 2011: S227). 
Other techniques - such as studying the demographic structure of herds based on kill-off patterns identified through age and sex ratios, or changes in species frequency, or the appearance of species in new habitats - have also been used when attempting to identify the earliest herding. These established zooarchaeological techniques, however, have their limitations and are not necessarily capable of identifying the very earliest animal manipulation within the primary habitat zones of these species.

Kill-off patterns and herd demography, a combination of the sex ratio and frequency of ages at death, are considered to be two of the most important indicators in relation to the study of animal management and domestication. Researchers have long held the belief that changes in killoff patterns and herd demography can be indicators of intentional human management and early herding (Perkins 1964; Bökönyi 1969; Hole et al. 1969; Ducos 1978; Meadow 1989). It has been observed that herding practices tend to result in the slaughter of young animals, particularly males; thus assemblages dominated by adult animals, both male and female, are seen to be representative of hunting (Zeder 2006 with references; Arbuckle 2008: 223, with references). Recently it has been argued that clear evidence for young male kill-off appears in the faunal record only in the early eighth millennium cal. BC considerably later than the origins of caprine management. If true, this reduces the effectiveness of the assessment of kill-off patterns as a method for documenting the beginnings of animal husbandry (Arbuckle, Atıc1 2013).

Nevertheless, although kill-off patterns may still be broadly useful in differentiating between the strategies of hunters and herders, both types of economic strategy can produce a wide variety of demographic patterns. Kill-off patterns from known hunter-gatherer sites can mimic those from more settled societies (Meadow 1989; Arbuckle 2008), while young male kill-off demography can be the result of hunter-gatherers targeting bachelor herds, or even specifically male elements such as the testes. It is clear that demographics on their own do not provide a clear-cut distinction between hunters and the earliest herders. In addition, the method is fraught with taphonomic issues (Munson 2000).

It is, however, possible that the earliest manipulation of animals, the very beginnings of herding, might be identified through changes in diet, as the very earliest management by humans affected the movement patterns of animals and hence their access to particular food/fodder; i.e. animals were removed from their natural habitats to be fed and managed by people. These founder flocks do not carry the morphological and genetic changes that characterise and identify later domesticates, but they could, potentially, carry evidence of changes in diet. Carbon and nitrogen stable isotopes provide signatures of animal diet and thus pasturing practices. Studies of $\delta^{13} \mathrm{C}$ and $\delta^{15} \mathrm{~N}$ values of bone collagen are well-understood indicators of past diets. As animals' movements start to be affected by human intervention, changes in their diets should occur (Pearson et al. 2007), and thus such a study should reveal indications of whether or not human intervention has occurred.

\section{Where and when did caprine domestication first occur?}

Relying solely on morphometrics - a sharp and rapid reduction in overall body size - the established consensus, until the 1990s, was that animal domestication (goats followed by sheep) occurred ca 8,500-8,000 cal. BC, around 1,000 years after the domestication of plants in the southern Levant. The focus for goat and sheep domestication was somewhere to the north and east of plant domestication, with a second independent area of goat domestication claimed for the southern Levant (Zeder 2008 with references).

Using demographic data rather than morphometrics, the earliest claims for managed/domesticated caprines now comes from southeastern Anatolia (fig. 1). M.A. Zeder (2011) claims managed sheep, using demographic data, as early as $8,950 \mathrm{cal}$. BC at Körtik Tepe, but the earliest evidence, to date, of managed caprines based on a suite of indicators, including morphological change, comes from Nevalı Çori: domesticated sheep at 8,550 cal. BC followed by goat at 8,250 cal. BC (Peters et al. 1999; 2005). At Çayönü, also in southeastern Anatolia, there is evidence to suggest caprines lived near or even within the confines of the site at ca 8,550 cal. BC (Peters et al. 2005).

Goat appears to have been introduced to Cyprus by ca 8,400-8,300 cal. BC, followed by sheep (Vigne 2011; Vigne et al. 2003). Elsewhere in southwestern Asia there is evidence to suggest that fully domesticated goats were present in southern Jordan at 'Ain Ghazal from ca 8,370 cal. BC (Wasse 2002), while at Abu Hureyra in northern Syria there are claims for domestic goat at ca 8,200 cal. BC (Moore et al. 2000: 469-71). Zeder claims the presence of herded goat by the eighth millennium, ca 7,950 cal. BC, at Ganj Dareh in the highlands of Iran (2005: 137; 2008). The evidence from Ali Kosh, some 500 years later (ca 7,550 cal. BC), also indicates the presence of managed goats (Zeder 2005; 2011). Recently, widespread traces of ruminant dung, dating to both pre- and post- $8,000 \mathrm{cal}$. BC, have been confirmed as present at both Sheikh-e Abad and Jani in the Zagros; at Sheikh-e Abad there is evidence to suggest that animals were almost certainly brought into the settlement (Matthews et al. 2010; 2013).

The presence of 'managed' caprines at Aşıklı Höyük has been demonstrated at ca 8,200 cal. BC (Stiner et al. 2014). This claim is based on a combination of age profiles, the presence of perinatal caprines on site and sexbased culling, as well as on-site evidence for possible 


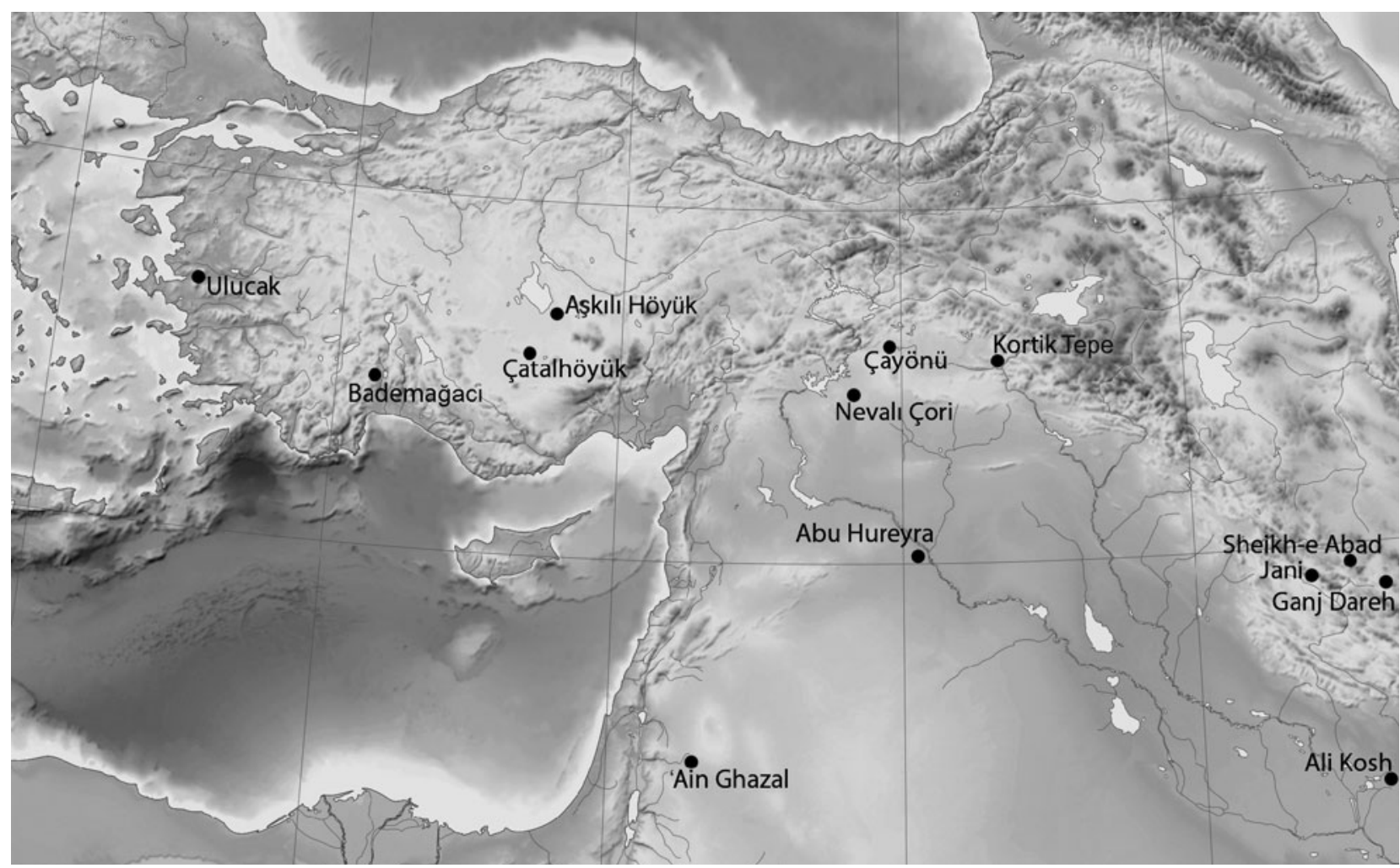

Fig. 1. Location map of southwestern Asia showing the sites with evidence for early caprine management.

penning deposits and herbivore dung. Currently there is no evidence for early herding or domesticates in central Anatolia between this and the earliest levels at Çatalhöyük East, ca 7,100 cal. BC (Russell, Martin 2005).

Alongside zooarchaeological research, recent genetic studies are also helping to unravel the origins of caprine domestication, revealing a diversity of MtDNA haplotypes (Naderi et al. 2007; 2008). A possible geographic focus for haplogroup A (the characteristic haplogroup of almost all present-day domestic goats) may have been eastern Anatolia, possibly extending to northern and central Zagros. Haplogroup C, on the other hand, possibly derives from wild goats domesticated somewhere on the central Iranian plateau and in central-southern Zagros. Other research suggests that there could have been at least five main centres of goat domestication (Luikart et al. 2006: 298, with references). More recently it has been argued that both wild and domestic goats probably descend from a single ancestral wild population, and that domestication occurred through sequential founding events rather than distinct founding events (Gerbault et al. 2012).

It appears that Ovis (sheep) too had more than one main centre of domestication. In 2006, M. Bruford and S.J. Townsend (2006: 313) suggested the presence of three centres of domestication, while a year later J.R.S. Meadows and colleagues (2007) argued for five MtDNA lineages (A, B, C, D and E) within the Levant and Anatolia. The existence of five MtDNA lineages is now well docu- mented (Demirci et al. 2013 with references) and suggests that sheep, along with goat, were taken from wild populations on multiple occasions. Thus the genetic evidence indicates that caprine domestication occurred more than once and at different locations throughout the Near East.

Contrary, therefore, to the belief held in the late 20th century - that the origins of agriculture lay within the southern Levant from where it quickly spread as a complete package of plants and animals (Bar-Yosef, Meadow 1995) - it seems that caprine herding/management did not emerge in a single area from where it was dispersed; rather, it seems to have occurred in several places at approximately the same time.

Work by B.S. Arbuckle and colleagues (2014), charting the spread of domesticated animals and husbandry techniques across Neolithic Anatolia, found several different trajectories, indicating that, within Anatolia, livestock did not move as part of a standard 'farming package'. There is a discernable difference between the areas where caprines, cattle and pigs are present as domesticates - the Lakes (Ulucak VI), southwestern Anatolia (Bademağacı) and southern Anatolia - and central Anatolia, where domestic pig never formed part of the agricultural economy. Arbuckle and colleagues (2014) argue that the data suggest a rapid westward movement of domesticates across southern Anatolia, possibly via a coastal route, while the concurrent absence of domestic cattle and pigs from central Anatolia suggests that this region was not 
directly involved in the earliest spread of domestic livestock to either the Lakes region or western Turkey, reaffirming the distinctive nature of the central Anatolian Neolithic tradition. Evidence from the earliest Neolithic communities in northwestern Anatolia indicates that communities utilised domesticated caprines and cattle, but did not keep domestic pigs, suggesting that the origin of the Neolithic in the northwest was also a distinctive process (Conolly et al. 2011; Özdoğan 2011).

\section{Animal exploitation in central Anatolia}

On the Konya plain, morphologically domesticated caprines are present from the foundation of Çatalhöyük East at ca 7,100 cal. BC (Russell, Martin 2005; Bayliss et al. 2014). How and when domesticated caprines became an integral part of the central Anatolian Neolithic economies, and their status and relationship within earlier communities, is only now beginning to be researched. There is currently no evidence for early herding, or domesticates, between the 'managed' caprines of Aşıklı Höyük, ca 8,200-7,500 cal. $\mathrm{BC}$, and the morphologically domesticated caprines of Çatalhöyük East at ca 7,100 cal. BC. The patterns seen at Aşıklı Höyük roughly parallel those seen across other regions of the Near East (Stiner et al. 2014).

The crucial period for the appearance of herding in central Anatolia appears to be the ca 900-year gap between the initial appearance of 'managed' caprines at Aşıklı Höyük and that of the domesticates of Çatalhöyük East: much of the ninth and the early eighth millennia cal. BC. Filling this gap will help establish central Anatolia's role with regard to the adoption of herding and caprine management within southwestern Asia.

This article looks at the dietary evidence from caprines at seven sites, all located on the Konya plain within central Anatolia and within $100 \mathrm{~km}$ of each other (fig. 2):

Epipalaeolithic Pınarbaşı: 14,000-11,000 cal. BC;

Ninth-millennium Pınarbaşı: 9,000-7,900 cal. BC;

Boncuklu: 8,400-7,500 cal. BC;

Canhasan III: 7,500-7,000 cal. BC;

Çatalhöyük East: 7,100-6,000 cal. BC;

Seventh-millennium Pınarbaşı: 6,500-6,000 cal. BC;

Çatalhöyük West: 6,000-4,500 cal. BC.

\section{Isotopes, diet and archaeology}

Carbon and nitrogen isotopes are routinely used to assess the palaeodiets of both humans and animals; sourced directly from the carbon and nitrogen biological cycles, these isotopes are assimilated into the consumer's tissue via food, forming a marker of the dietary average of protein consumed over a period of months or years. All food consumed by living organisms contains carbon and nitrogen, which is synthesised to become body protein; thus analysis of the carbon and nitrogen in the tissues of a

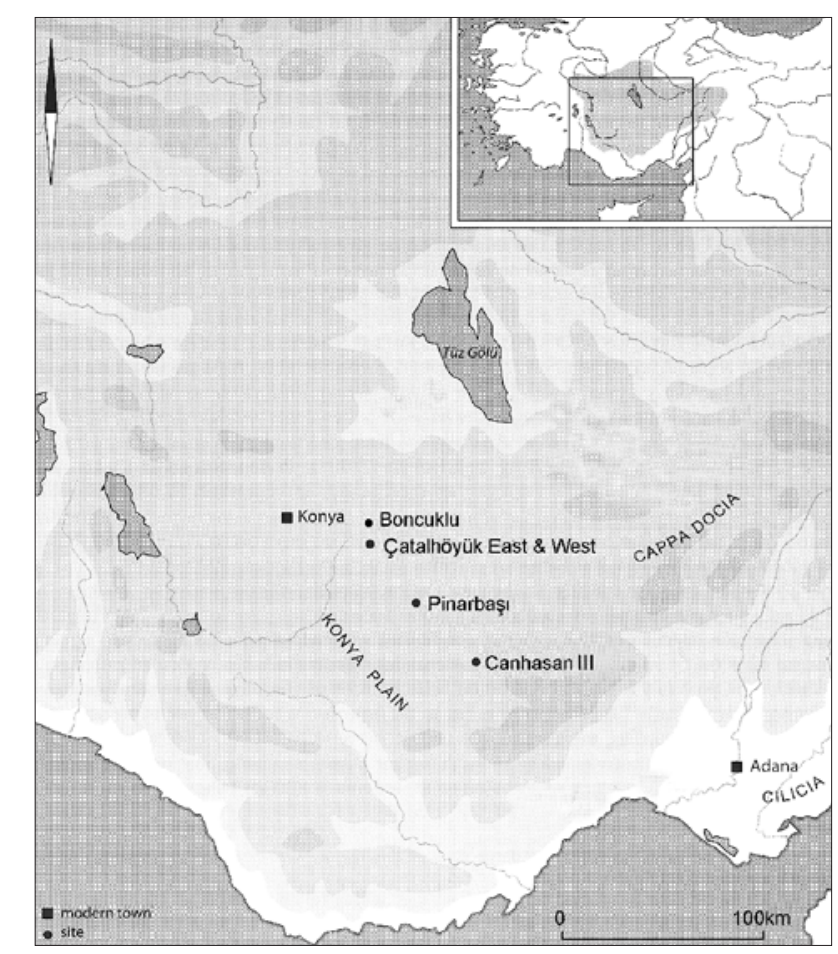

Fig. 2. Locations of the case-study sites.

consumer can provide some idea of its source and thereby identify the consumer's diet (DeNiro, Epstein 1978; 1981; Ambrose, Norr 1993).

Carbon enters the food chain through plants undergoing photosynthesis. It is then incorporated at each successive stage of the food chain, so that, regardless of trophic level, the different types of plant that form the foundation of the food web can be determined. It is possible, therefore, to undertake dietary analysis using the ${ }^{13} \mathrm{C} /{ }^{12} \mathrm{C}$ ratio of carbon found in the bone collagen of animals, regardless of their position in the food chain (DeNiro, Epstein 1978). At the base of the food chain there is an enrichment of approximately 5\%o from plant to consumer (Ambrose, Norr 1993).

For the purposes of this study there are two classes of plant: $\mathrm{C}_{3}$ and $\mathrm{C}_{4}$. Typical $\mathrm{C}_{3}$ plants include trees (and therefore most fruits and nuts), temperate grasses, legumes and most major food crops, including wheat, barley, rye and rice. It is estimated that $90 \%$ of terrestrial plant species on the planet follow the $\mathrm{C}_{3}$ pathway. Typical $\mathrm{C}_{4}$ plants include sugarcane, sorghum and millet. Although it is generally stated that $\mathrm{C}_{4}$ plants are adapted for warm, highlight habitats with limited moisture availability, this is an oversimplification: $\mathrm{C}_{4}$ plants do often dominate hot, dry sites, but they can also dominate warm, wet habitats, as well as being absent from certain hot, dry locations (Sage et al. 1999). $\mathrm{C}_{4}$ species have been identified on the Konya plain (Fairbairn et al. 2005; 2014; Bogaard et al. 2013; Baird et al. 2013). The two diverse photosynthetic pathways followed by $\mathrm{C}_{3}$ and $\mathrm{C}_{4}$ plants result in a distinc- 
tive range of carbon isotope ratios for each photosynthetic method: $\mathrm{C}_{3}$ plants typically have carbon isotope ratios between $-34 \%$ and $-22 \%$; $\mathrm{C}_{4}$ plants range from $-20 \%$ to $-7 \%$. $\mathrm{C}_{3}$ plants have a global mean of $-27.1 \pm 2.0 \%$; $\mathrm{C}_{4}$ plants have a global mean of $-13.1 \pm 1.2 \%$ : there is no overlap between the ranges (O’Leary 1981; 1988).

Nitrogen isotopes both reflect the amount of dietary protein in a diet and distinguish trophic shifts within the foodweb: for example, herbivore to carnivore and marine plants from terrestrial ones. Nitrogen enters the food chain through plants, as either adsorbed nitrogenous compounds in the soil or fixed from atmospheric nitrogen (Cheng et al. 1964). This nitrogen is then incorporated higher up the food chain. Any single trophic transfer is likely to range between ca 2\%o and 5\% (Post 2002; Hedges, Reynard 2007). This is known as the trophic level effect and can be used to understand the relationship between the various consumers in the food chain. Although the value for ${ }^{15} \mathrm{~N}$ is relatively constant within the atmosphere, isotope distribution can differ appreciably in other nitrogenous forms, particularly in biological systems (Delwiche, Steyn 1970). The relationship between the $\delta^{15} \mathrm{~N}$ values of soil and plants, and factors such as aridity, salinity, fire and grazing is complex, involving an intricate interplay between the quantity of nitrogen flowing through the ecosystem, its source, utilisation and fractionation (Handley et al. 1999). So, although nearly all the nitrogen incorporated into the foodweb emanates from a limited number of sources, local variations in $\delta^{15} \mathrm{~N}$ values do occur, not only between tropic levels, but also within them (Ambrose 1993). Table 1 summarises the various factors and their potential effects on $\delta^{15} \mathrm{~N}$ values.
Given the complexity of plant fractionation and photosynthesis, it is no surprise that the $\delta^{13} \mathrm{C}$ values of plants are potentially sensitive to environmental factors affecting the flow of $\mathrm{CO}_{2}$ (table 2). Although in general the differences in $\delta^{13} \mathrm{C}$ values are small, only a few per mille (\%o), they are significant, potentially reflecting differences in diet or, possibly, differences in the climate/environment (Heaton 1999). It is important therefore, when using isotopes as indicators of palaeodiet, animal or human, to appreciate these potential sources of variation and their possible effects. The general premise is that $\mathrm{C}_{3}$ plant $\delta^{13} \mathrm{C}$ values are lower in closed and humid environments, and higher in hot, dry ones, and that this phenomenon is reflected throughout the foodweb (Ambrose 1993: 90, table 2).

\section{Environmental setting}

The geographic position of central Anatolia means that it sits on the interface of climatic systems that affect the northern hemisphere and inter-tropical Africa (Roberts et al. 2001). An increasing number of isotope records, lake isotope palaeohydrology and non-lacustrine evidence (for example speleothems and marine sapropel layers) support the theory that there was a relatively wet period at the start of the Holocene, which was probably the result of high winter precipitation rather than a year-round increase in moisture (Roberts et al. 2001; Wick et al. 2003; Jones et al. 2007; Jones, Roberts 2008). Research results also indicate that the Early Holocene was the wettest period between the present and 25,000 years ago, with a rapid increase in moisture at the onset of the Holocene, followed by a period of wetness until ca 4,550 cal. BC, after which a much drier climate ensued (Jones et al. 2007). L. Wick

\begin{tabular}{|llll|}
\hline Manuring & Less negative $\delta^{15} \mathrm{~N}$ values & +3.1 to $+8 \%$ enrichment & $\begin{array}{l}\text { Choi et al. 2002; Bol et al. } \\
\text { 2005; Bogaard et al. 2007; } \\
\text { Saline conditions }\end{array}$ \\
& Less negative $\delta^{15} \mathrm{~N}$ values & +5 to $+17 \%$ enrichment & $\begin{array}{l}\text { Senbayram et al. 2008 } \\
\text { Heaton 1987; Mizutani, Wada } \\
\text { 1988; van Groenigen, van }\end{array}$ \\
& & Kessel 2002
\end{tabular}

Table 1. Summary of factors and their effect on plant $\delta^{15} N$ values. 


\begin{tabular}{|c|c|c|c|}
\hline $\begin{array}{l}\text { Temperature (changes } \\
\text { not irrefutably due to } \\
\text { temperature) }\end{array}$ & Less negative $\delta^{13} \mathrm{C}$ values & $\begin{array}{l}\text { Less than }+0.5 \% 0 \\
\text { enrichment }\end{array}$ & $\begin{array}{l}\text { Lipp et al. 1991; van Klinken et } \\
\text { al. 1994; Hemming et al. 1998; } \\
\text { Heaton } 1999\end{array}$ \\
\hline $\begin{array}{l}\text { Altitude (changes not } \\
\text { irrefutably due to } \\
\text { altitude) }\end{array}$ & Less negative $\delta^{13} \mathrm{C}$ values & $+3 \%$ enrichment & $\begin{array}{l}\text { Tieszen et al. 1974; Körner et } \\
\text { al. 1988; } 1991\end{array}$ \\
\hline Aridity (low rainfall) & $\begin{array}{l}\text { Less negative/higher } \delta^{13} \mathrm{C} \\
\text { values }\end{array}$ & +2 to $+4 \%$ enrichment & $\begin{array}{l}\text { Ehleringer, Cooper 1988; John- } \\
\text { son et al. 1989; Tieszen 1991; } \\
\text { Heaton } 1999\end{array}$ \\
\hline $\begin{array}{l}\text { Saline conditions } \\
\left(C_{3} \text { plants }\right)\end{array}$ & Less negative $\delta^{13} \mathrm{C}$ values & +1 to $+2 \%$ enrichment & $\begin{array}{l}\text { Neales et al. 1983; Downton et } \\
\text { al. 1985; van Groenigen, van } \\
\text { Kessel } 2002\end{array}$ \\
\hline \multicolumn{4}{|c|}{ Mean $\delta^{13} \mathrm{C}$ value } \\
\hline $\begin{array}{l}\text { Saline conditions } \\
\left(C_{4} \text { plants }\right)\end{array}$ & More negative $\delta^{13} \mathrm{C}$ values & -0.25 to $+4 \%$ enrichment & $\begin{array}{l}\text { Bowman et al. 1989; Sandquist, } \\
\text { Ehleringer 1995; Maricle, Lee } \\
2006\end{array}$ \\
\hline Canopy effect & More negative $\delta^{13} \mathrm{C}$ values & -2 to $-5 \%$ enrichment & $\begin{array}{l}\text { Medina, Minchin 1980; van der } \\
\text { Merwe, Medina 1989; Broad- } \\
\text { meadow et al. 1992; Cerling et } \\
\text { al. 2004; Koch et al. } 2004\end{array}$ \\
\hline
\end{tabular}

Table 2. Summary of factors and their effect on plant $\delta^{13} C$ values.

and colleagues (2003) suggest that there could have been warm, dry weather during the growing season, while M.D. Jones and colleagues $(2005 ; 2007)$ have calculated that precipitation was some $25-40 \%$ lower than at present during the Late Pleistocene and some $20-40 \%$ higher than at present during the Early Holocene.

The following section summarises climate change in the Konya basin from the Late Glacial into the Early Holocene. The wetter, warmer conditions of the Greenland Interstadial 1 appear to have lasted until ca $10,800 \mathrm{cal}$. BC when colder year-round conditions, with relatively frigid winters and mild summers, took over in Greenland Stadial 1 (Younger Dryas). In the Early Holocene, ca 9,700 cal. $\mathrm{BC}$, warm winters and hot summers became the norm. It is thus clear that there were changes within the palaeoenvironment of the Konya plain over the period covered by this research. Epipalaeolithic Pınarbaşı is dated to the Greenland Interstadial 1 (GI-1) (ca 14,000-11,000 cal. $\mathrm{BC}$ ), with Pleistocene conditions closest to those of the Early Holocene, while ninth-millennium Pınarbaşı lies within the wetter part of the Early Holocene. The Konya plain could have experienced increasing aridity from the seventh millennium cal. BC, especially around the 6,200 cal. BC event, but conditions would still have been wetter and cooler than today. Jones and colleagues (2007) provide a very useful summary of average temperature over this period in central Anatolia.

$\begin{array}{ll}\text { Glacial } & 4^{\circ} \mathrm{C} \\ \text { Late Glacial Interstade } & 8^{\circ} \mathrm{C} \\ \text { Late Glacial Stade } & 5^{\circ} \mathrm{C} \\ \text { Early Holocene } & 9^{\circ} \mathrm{C} \\ \text { Late Holocene } & 10^{\circ} \mathrm{C}\end{array}$

These temperatures are based on lake isotope palaeohydrological research undertaken at Lake Eski Acıgöl and are, therefore, of particular relevance to the Konya plain. They show a substantial increase in temperature during the Early Holocene (Jones et al. 2007). In the briefest of summaries: the evidence suggests that the onset of the Holocene $(9,700$ cal. BC) was marked by rapid (ca 50 years) increases in humidity and temperature, decreases in salinity and fluctuating seasonal rainfall (Roberts et al. 2001; Wick et al. 2003).

The factors most likely to affect the flora of the study area are saline conditions and/or increased aridity due to low rainfall and/or the seasonal drying out of wetlands. All the sites considered in this study lie within a relatively small area and within one ecozone; therefore, spatial variation is unlikely to produce variability between sample sets from different sites. It is, however, possible that the results might relate, at least in part, to these documented climatic/environmental changes. Therefore, in order to control for environmental change over time and to ascertain whether dietary changes were independent of 
climatic/environmental change, control species were included in the study. The control species - hare and deer - were chosen because management by humans is considered highly unlikely at this period; samples were taken from all sites. The dietary isotopic values of the control species suggest consistency of plant carbon and nitrogen isotope values throughout the timeframe of the study, indicating that the plant baseline is as valid for the Epipalaeolithic as it is for the sixth millennium cal. BC.

\section{Methodology}

Samples were taken from a comprehensive range of contexts from each case-study site. Preservation of bone at all sites was good, although collagen yield was better at some than at others. It should be noted that the highly fragmented nature of the faunal assemblages at the earlier sites, particularly Epipalaeolithic Pınarbaşı, ninth-millennium Pınarbaşı and Boncuklu, inevitably meant that fewer bones could be identified to species and hence were available for isotope sampling. Samples were selected from adult specimens identified to species; when necessary, Boessneck 1969 alongside the modern reference collections held at Çatalhöyük East and the University of Liverpool were used to separate Ovis from Capra. Samples, weighing ca $2 \mathrm{~g}$, were cut as chunks from fused, compact, long-bone shafts (avoiding articulations, cut marks and pathology). Wherever possible, the same element, for example the right humerus, was used within a single context, thereby reducing the likelihood of unwittingly duplicating samples from the same individual. Only material from secure contexts was used. Care was taken not to use young/suckling individuals. No burnt bone was sampled.
Samples were taken using a diamond-tipped drill bit (table 3). Diamond is unlikely to contaminate bones with an external source of carbon or nitrogen.

\section{The plant baseline}

Sixty-two charred archaeological plants from Çatalhöyük East were used by Jessica Pearson (University of Liverpool) to create a local floral baseline for the Konya plain (Pearson 2004: 134). The charred plant assemblage was studied by Andrew Fairbairn (University of Queensland) using detailed reference collections of Anatolian botanical specimens held at University College London (Hillman Collection) and the British Institute at Ankara (Nesbitt Collection) and by Amy Bogaard (University of Oxford).

The aim of this part of the study was two-fold: firstly, to confirm, by direct measurement, that the $\delta^{13} \mathrm{C}$ values of the $\mathrm{C}_{3}$ and $\mathrm{C}_{4}$ plants from sites on the Konya plain fall within the range expected for their photosynthetic physiology; and, secondly, to compare the results from the Konya plain with the universal distribution of $\mathrm{C}_{3}$ and $\mathrm{C}_{4}$ plants published by M.H. O’Leary (1988). Given worldwide variability it was important to establish a local mean for $\mathrm{C}_{3}$ and $\mathrm{C}_{4}$ plants. Figure 3 shows the universal distribution of these plants as published by O'Leary (1988) compared to the charred archaeological plants from Çatalhöyük. Using values from Çatalhöyük East, rather than the universal results, a consumer with an exclusively $\mathrm{C}_{3}$ diet would have carbon isotope values of around $-18 \%$, while an exclusively $\mathrm{C}_{4}$ feeder would have carbon isotope values of around $-7 \%$. The variation between the global means and those from the Konya plain confirms the importance of using local plants to create a baseline (Pearson 2004; Pearson et al. 2007; Middleton 2014).

1. Sampling. Compact bone chunks, weighing $0.3-0.6 \mathrm{~g}$, were taken using a diamond-tipped cutting wheel. The starting weight of the bone chunk was noted.

2. De-mineralisation. Bone chunks were immersed whole in a test tube of $0.5 \mathrm{M} \mathrm{HCl}_{(\mathrm{aq})}$. Poorly preserved samples were refrigerated at $4^{\circ} \mathrm{C}$ during de-mineralisation to slow the reaction rate. Well-preserved samples were usually demineralised at room temperature. Acid was changed as required. Once the bone was fully de-mineralised it was washed three times with ultrapure water (produced by using a Purite Neptune purifier) to neutral $\mathrm{pH}$. Where necessary, EZee filters were used to prevent loss of collagen.

3. Gelatinisation. $\mathrm{pH} 3 \mathrm{H}_{2} \mathrm{O}(\mathrm{HCl})$ was added to the sample, a gelatinising cap was put on the test tube and the sample was heated at $\sim 70^{\circ} \mathrm{C}$ for 48 hours in a hot block. The gelatinous solution was then filtered through an $8 \mu \mathrm{m}$ EZee filter, transferred to a plastic test tube and sealed with Parafilm.

4. Lyophilisation. The Parafilm lid was perforated and samples were frozen at $\sim-25^{\circ} \mathrm{C}$ overnight before being placed in a freeze drier until dry ( 48 hours).

5. Bulk yield. The bulk yield of collagen extracted was weighed.

6. Weighing. Samples were weighed in triplicate into tin capsules ready for combustion.

Table 3. Methodology for collagen extraction from whole archaeological bone (after Richards, Hedges 1999; Pearson 2004). 


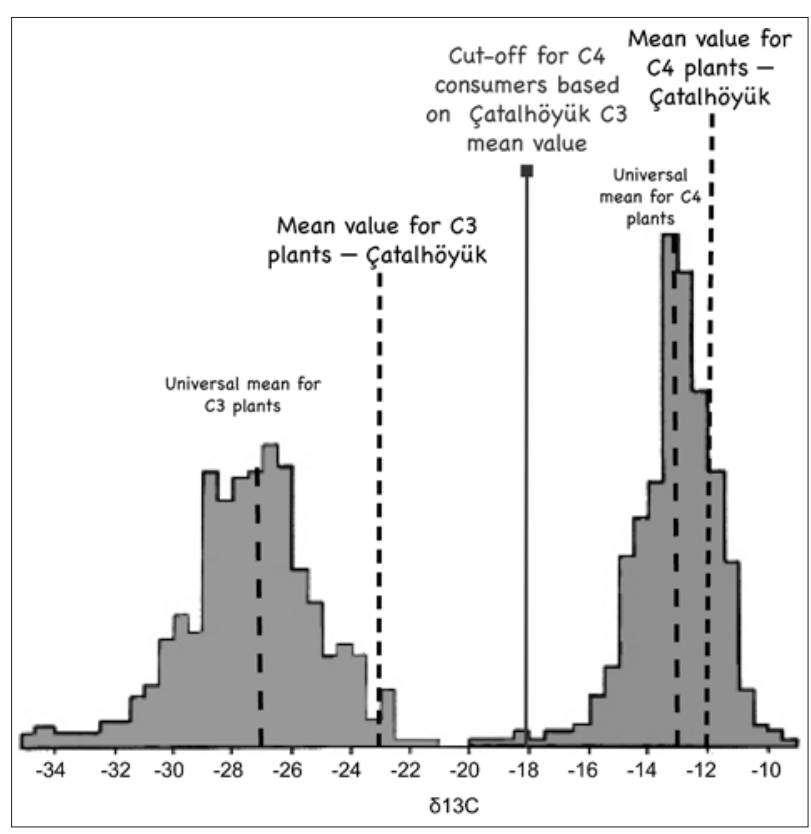

Fig. 3. Histogram showing the $\delta^{13} C$ distribution and mean values of $\mathrm{C}_{3}$ and $\mathrm{C}_{4}$ plants from Çatalhöyük East plotted against the universal values as given in O'Leary 1988. The cut-offfor $\mathrm{C}_{4}$ plants for Çatalhöyük East is also shown.

\section{Sample preparation}

For details of the methodology used for collagen extraction from whole archaeological bone, see table 3. All chemicals used were of analytical (AR) grade or above and all water used was ultrapure (produced by using a Purite Neptune purifier), typically $18.2 \mathrm{M} \Omega . \mathrm{cm}$ resistivity at $25^{\circ} \mathrm{C}$ with a total organic carbon (TOC) content of $<1 \mathrm{ppb}$.

The bone collagen extraction protocol used followed a modified Longin 1971 method (Brown et al. 1988). This method uses dilute aqueous hydrochloric acid (dil. $\left.\mathrm{HCl}_{(\mathrm{aq})}\right)$ which increases the likelihood of recovering collagen from poorly preserved samples. It is known that the use of more concentrated hydrochloric acid can cause collagen destruction; indeed, some extraction methods have proved so severe that, although they have successfully eliminated contaminants, they have also destroyed most of the original collagen (Longin 1971). Hydrochloric acid eliminates soil-derived carbonates, phosphates and fulvic acids, while solubilisation, followed by filtration, ensures the removal of any acid-insoluble particulate matter (Ambrose 1990).

The weighed samples were measured at the Isotope Geoscience Laboratory of the Natural Environment Research Council (UK) using continuous flow-elemental analysis-isotope ratio mass spectrometry (CF-EA-IRMS).

Using data from Epipalaeolithic Pınarbaşı - where caprines are deemed to be morphologically wild and the hunter-gatherer lifestyle suggests less likelihood of dietary manipulation - a local unaffected caprine dietary signature was created. Data from Çatalhöyük East provided an affected dietary signature for early morphologically domesticated caprines, while deer (Cervid) and hare (Lepus) were used to establish the degree of environmental change over time and its impact on diet. Appendix A details the isotope data from each site. Using these two dietary signatures it should be possible to chart changes at sites where no morphometric or demographic data suggestive of early herding or domesticates exist, thereby extending our knowledge and understanding of how and when caprines came under human control in central Anatolia.

\section{Results and discussion}

Note that the $\mathrm{C}_{3} / \mathrm{C}_{4}$ boundary established above (fig. 3 ) is marked on each graph. In the graph legends the sites are referred to by code: Epipalaeolithic Pınarbaş1: EPb; ninthmillennium Pınarbaşı: 9thPb; Boncuklu: Bon; Canhasan III: CanIII; Çatalhöyük East: ChE; seventh-millennium Pınarbaş1: 7thPb; Çatalhöyük West: ChW.

In order to confirm that changes in diet were due to human intervention rather than environmental change, two wild species - deer and hare - were sampled. As there is no linear trend through time in either carbon or nitrogen, nor are there any changes that are broadly coincident with major climatic changes, the results, although few in number, suggest that environmental/climatic change over time did not affect the diet of wild animals living on the Konya plain (fig. 4). It is probable, therefore, that any changes witnessed in the dietary signatures of the caprines are the result of human impact. It is notable that none of the results for deer and hare sit above $11 \%$ on the $\delta^{15} \mathrm{~N}$ scale: this appears to be a general rule for samples taken from sites on the Konya plain where the animals are considered to be morphologically wild (Middleton 2014).

\section{The unaffected dietary signature}

Although there is very little morphological or demographic data from Epipalaeolithic Pınarbaş1, due to the fragmented nature of the assemblage, the dating of the site $(14,000$ 11,000 cal. BC) strongly suggests that the caprines were wild and consuming diets unaffected by humans. The carbon and nitrogen isotope results from this site (fig. 5) should, therefore, form a good faunal baseline from which to analyse chronologically subsequent sites.

What is notable is the consistency of $\delta^{15} \mathrm{~N}$ and $\delta^{13} \mathrm{C}$ levels within the caprines. All but one lie within the exclusively $\mathrm{C}_{3}$ sector of the graph and have consistent levels of $\delta^{15} \mathrm{~N}$, with more than $80 \%$ having a difference of less than $2 \%$. Given that the $-18 \%$ is not a clean cut-off, the animals lying on or very close to the right-hand side of the boundary are unlikely to have consumed significant 
amounts of $\mathrm{C}_{4}$. Work done at Çatalhöyük, Pınarbaşı and Boncuklu (Fairbairn et al. 2005; 2014; Baird et al. 2012; 2013; Bogaard et al. 2013) has confirmed the presence of wild $\mathrm{C}_{4}$ plants on the Konya plain, and within central Anatolia graze appears to be a mixture of $\mathrm{C}_{3}$ and $\mathrm{C}_{4}$ grasses and sedges (Pearson 2013). The presence of $\mathrm{C}_{4}$ plants in the dietary signature of one out of 22 samples $(4.5 \%)$ is not, therefore, unexpected. The overall picture suggests that although $\mathrm{C}_{4}$ and wild saline marsh plants were present on the Konya plain they were not a regular food of choice for the local sheep and goat or, alternatively, they were uncommon within their local natural habitats.

To this embryonic framework can be added the results from ninth-millennium Pınarbaşı (fig. 6), where, based on morphometrics, the caprines are believed to be wild. In terms of collagen extraction and usable results, this was the least successful site. Of 59 bone samples taken, only $22 \%$ produced 'good' collagen (see Appendix A). Modern bone has an atomic $\mathrm{C}: \mathrm{N}$ ratio of 3.21 (Ambrose 1993). In order to retain in vivo isotope ratios, archaeological bone needs to fall within the range 2.9-3.6 (DeNiro 1985; Ambrose 1990; 1993); therefore, all samples with atomic C:N ratios outside the 2.9-3.6 range were discarded. G.J. van Klinken (1999) argues for a range of 3.1-3.5 and that anything outside this range should be viewed with caution. Accordingly, any samples falling outside the 3.1-3.5 range were viewed with caution.

The consistency and clustering of results from Epipalaeolithic Pınarbaşı and ninth-millennium cal. BC Pınarbaşı is notable and suggests an impressive degree of consistency vis-à-vis habitat and grazing - despite changes in the environment and climate over the 5,000 years from the GI-1 into the beginning of the Holocene. Such consistency could also indicate the continued use, over time, of particular hunting grounds by the people using the Pınarbaşı site. The clustering of results suggests that there is little or no discernable distinction between sheep and goat; hence, for the purposes of this research, sheep and goat can be considered under the single label 'caprine'.

Although the morphological data suggest that the caprines from ninth-millennium Pınarbaşı were wild, the fact that early herding has been argued for sites of the same period in Cappadocia, southeastern Anatolia, the southern Levant and Syria means that the possibility that humans were beginning to have an impact on the natural rhythms and diets of caprines at ninth-millennium Pınarbaşı must

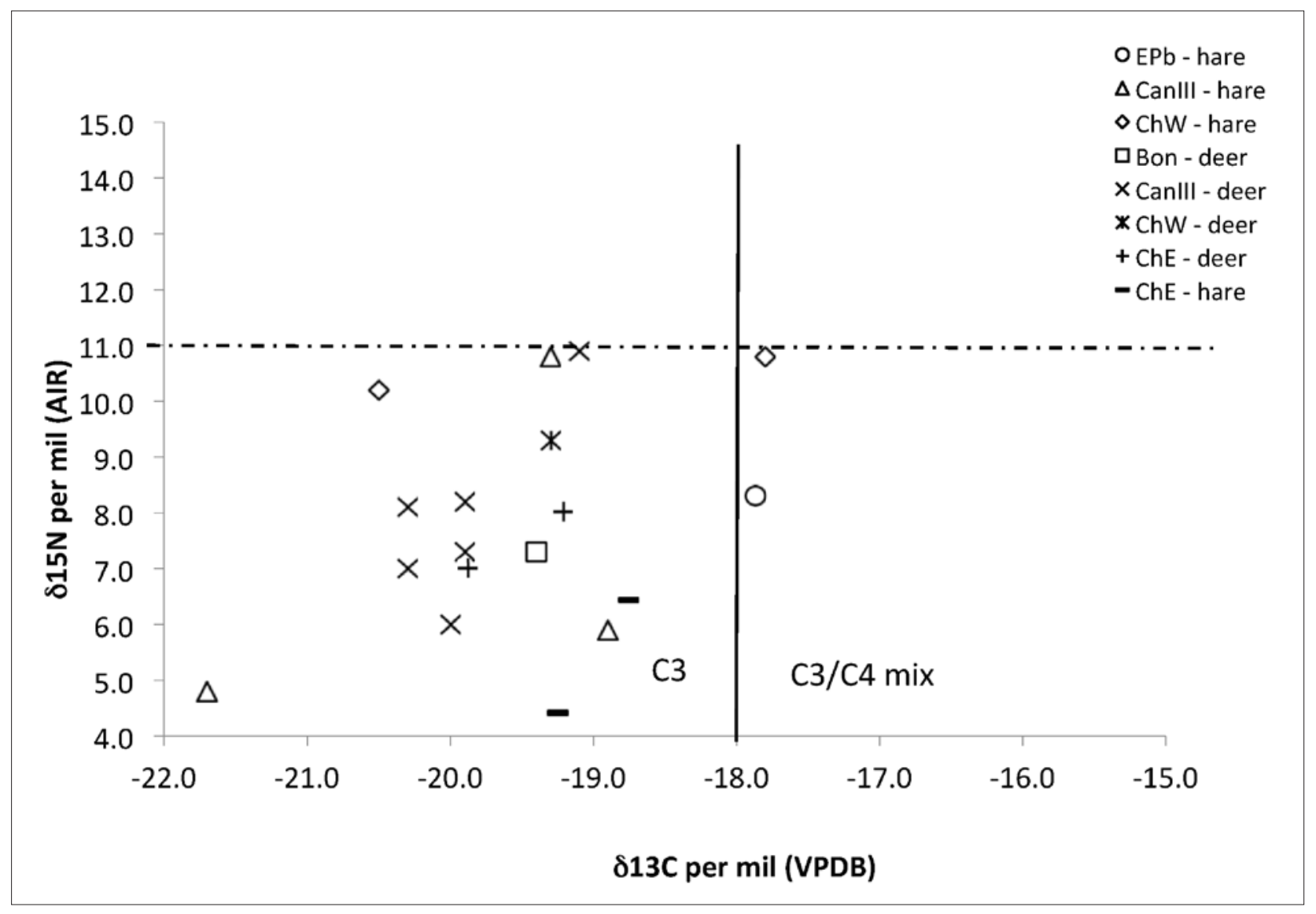

Fig. 4. Carbon and nitrogen results for deer and hare from sites spanning 13,000-5,400 cal. BC. Note that none of the results sit above $11 \%$ on the $\delta^{15} \mathrm{~N}$ scale. EPb = Epipalaeolithic Pınarbaşl; Bon = Boncuklu; CanIII = Canhasan III; ChE $=$ Çatalhöyük East; ChW= Çatalhöyük West. 


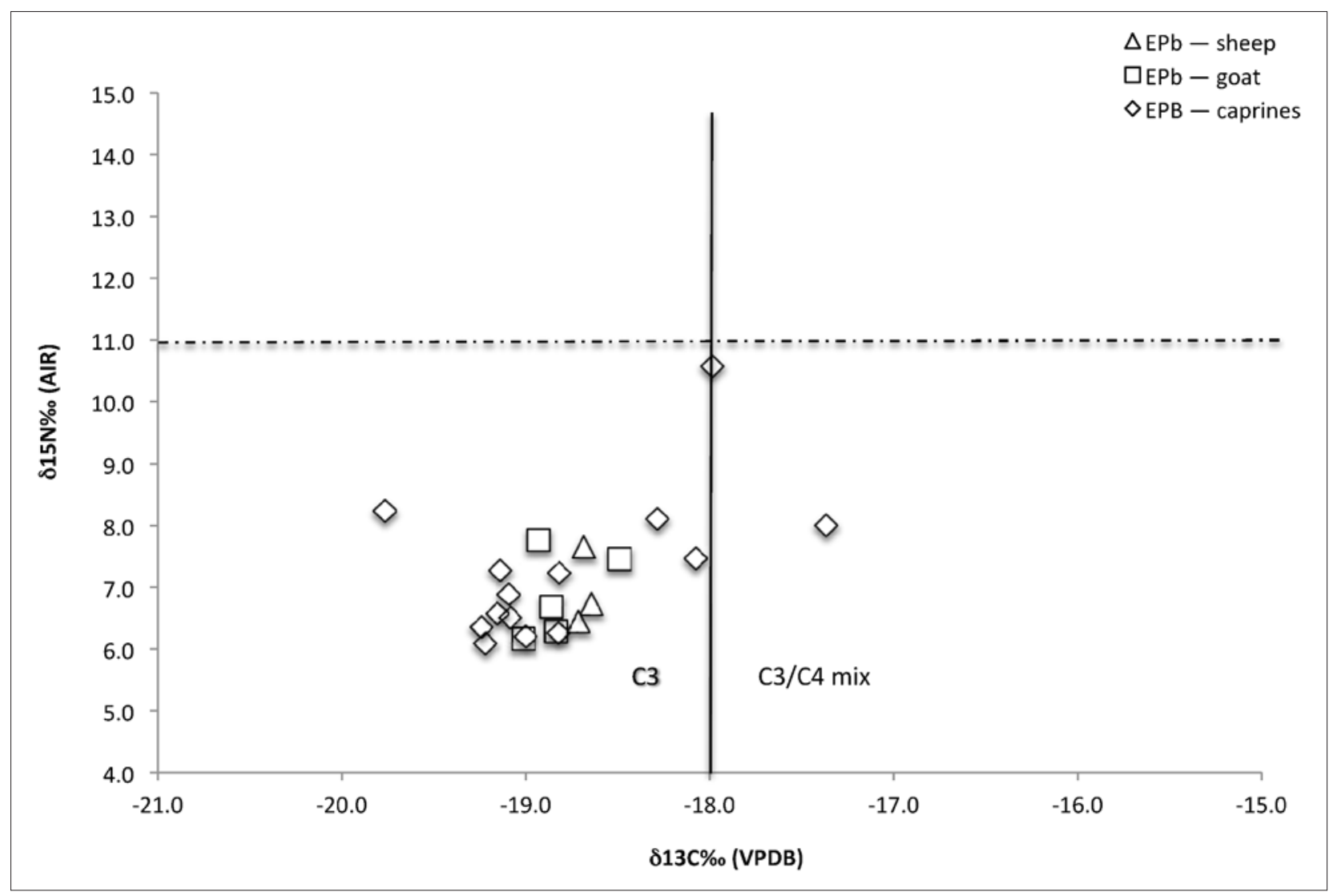

Fig. 5. The unaffected range of sheep and goat based on the results from Epipalaeolithic Pınarbaşl, where caprines are considered to be wild: all but one fall below $8.2 \%$ on the $\delta^{15} \mathrm{~N}$ scale. EPb $=$ Epipalaeolithic Pınarbaşl.

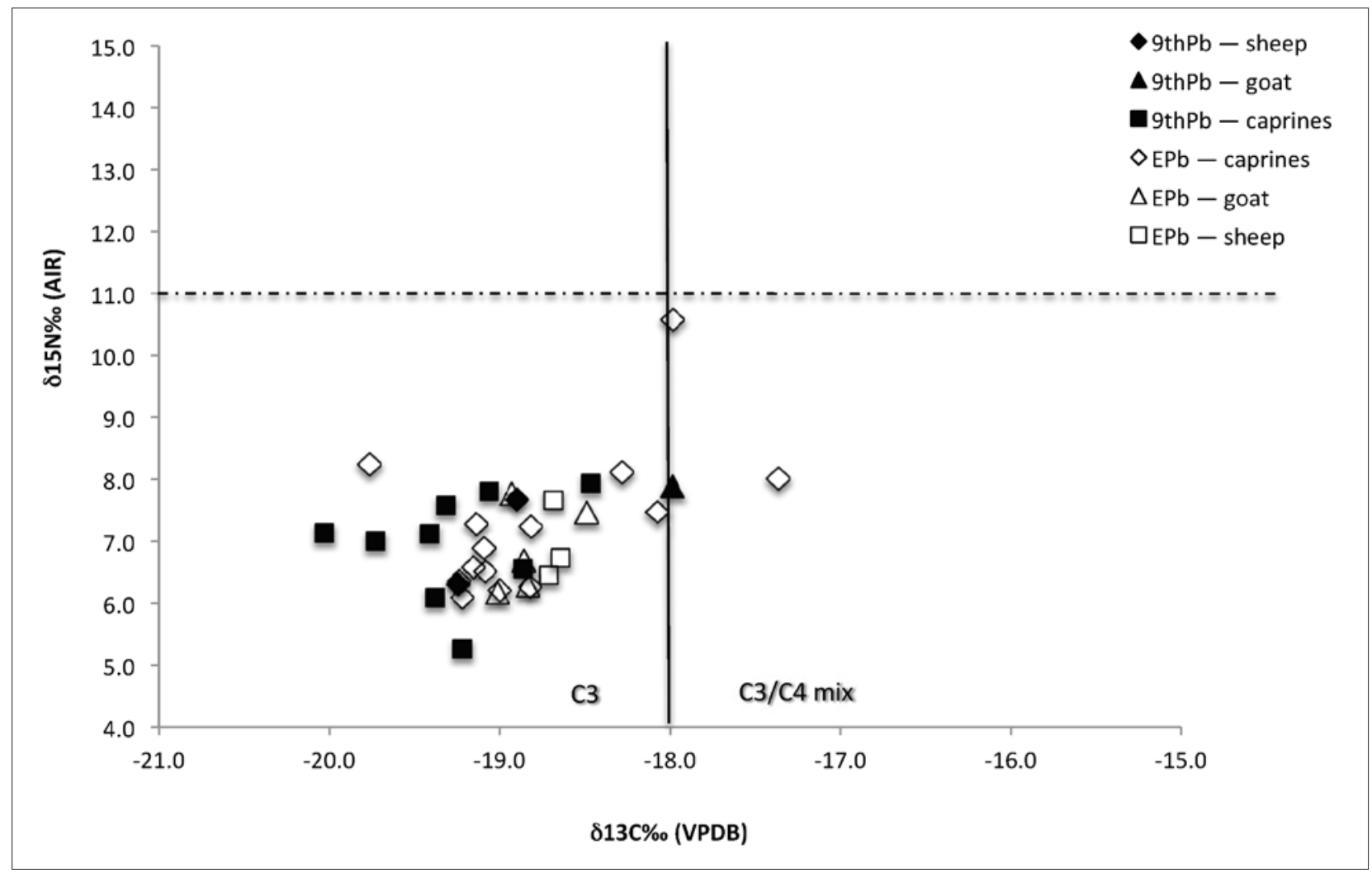

Fig. 6. Caprines from Epipalaeolithic Pınarbaşı and ninth-millennium Pınarbaşı: all but one fall below $8.2 \%$ on the $\delta^{15} \mathrm{~N}$ scale. EPb = Epipalaeolithic Pınarbaşı; 9thPb = ninth-millennium Pınarbaşı. 
be considered. However, given the similarities between the isotopic data from Epipalaeolithic Pınarbaşı and ninthmillennium Pınarbaşı, it seems that no such 'impact' was underway and that the carbon and nitrogen isotope results confirm the unaffected status of caprines at ninth-millennium Pınarbaşı.

The local plant baseline combined with the dietary signatures of the 'wild' caprines from Epipalaeolithic Pınarbaşı and ninth-millennium Pınarbaşı provide an unaffected dietary signature for caprines living on the Konya plain (fig. 7): $100 \%$ of the samples cluster below $11 \%$ on the $\delta^{15} \mathrm{~N}$ scale and within a $3 \%$ range on the $\delta^{13} \mathrm{C}$ scale; all but one cluster below $8.2 \%$ on the $\delta^{15} \mathrm{~N}$ scale. The one caprine that sits above $8.2 \%$ but below $11 \%$ on the $\delta^{15} \mathrm{~N}$ scale comes from Epipalaeolithic Pınarbaşı and its dietary signature matches that of a Bos primigenius (aurochs) from the same site. It is probable that these two animals came from the same environment, and that this caprine was killed in an area away from the usual caprine hunting grounds.

\section{The affected dietary signature}

Within the study, Çatalhöyük West is the most recent site chronologically. It should, therefore, provide a suitable dietary signature for fully domesticated caprines living on the Konya plain in the sixth millennium cal. BC. Morphologically and demographically, the caprines found at Çatalhöyük West appear to have been domesticated.
Figure 8 shows caprines from Çatalhöyük West plotted against the unaffected signature; there are clear differences between the caprines from the early sites and those from Çatalhöyük West. The increasing spread and move towards heavier carbon and enriched nitrogen of the Çatalhöyük West samples suggests dietary differences between affected and unaffected caprines, with the domesticates (affected) having more $\mathrm{C}_{4}$ in their diet and increasing levels of $\delta^{15} \mathrm{~N}$.

As most of the caprines found at Çatalhöyük East are domesticates (Russell, Martin 2005: 950), it makes sense to add the results from Çatalhöyük East and contemporary seventh-millennium Pınarbaşı to confirm, or query, the affected dietary signature obtained from the Çatalhöyük West caprines and to understand the diet of the earliest unequivocally domestic caprines on the plain. Figure 9 incorporates the caprine results from Çatalhöyük East and seventh-millennium Pınarbaşı sampled specifically for this study and seems to confirm the existence of a distinctive dietary signature relating to managed caprines.

Work by E. Henton (2013), looking at oxygen isotopes, indicates that throughout the lifetime of Çatalhöyük East the majority of sheep lived their lives, in terms of altitude and water sources, in a broadly similar area. Given that they seem to have experienced arid summers, Henton suggests that they lived within the relatively exposed conditions of the Konya plain. Only a small percentage appear to have been moved uphill into areas with cooler

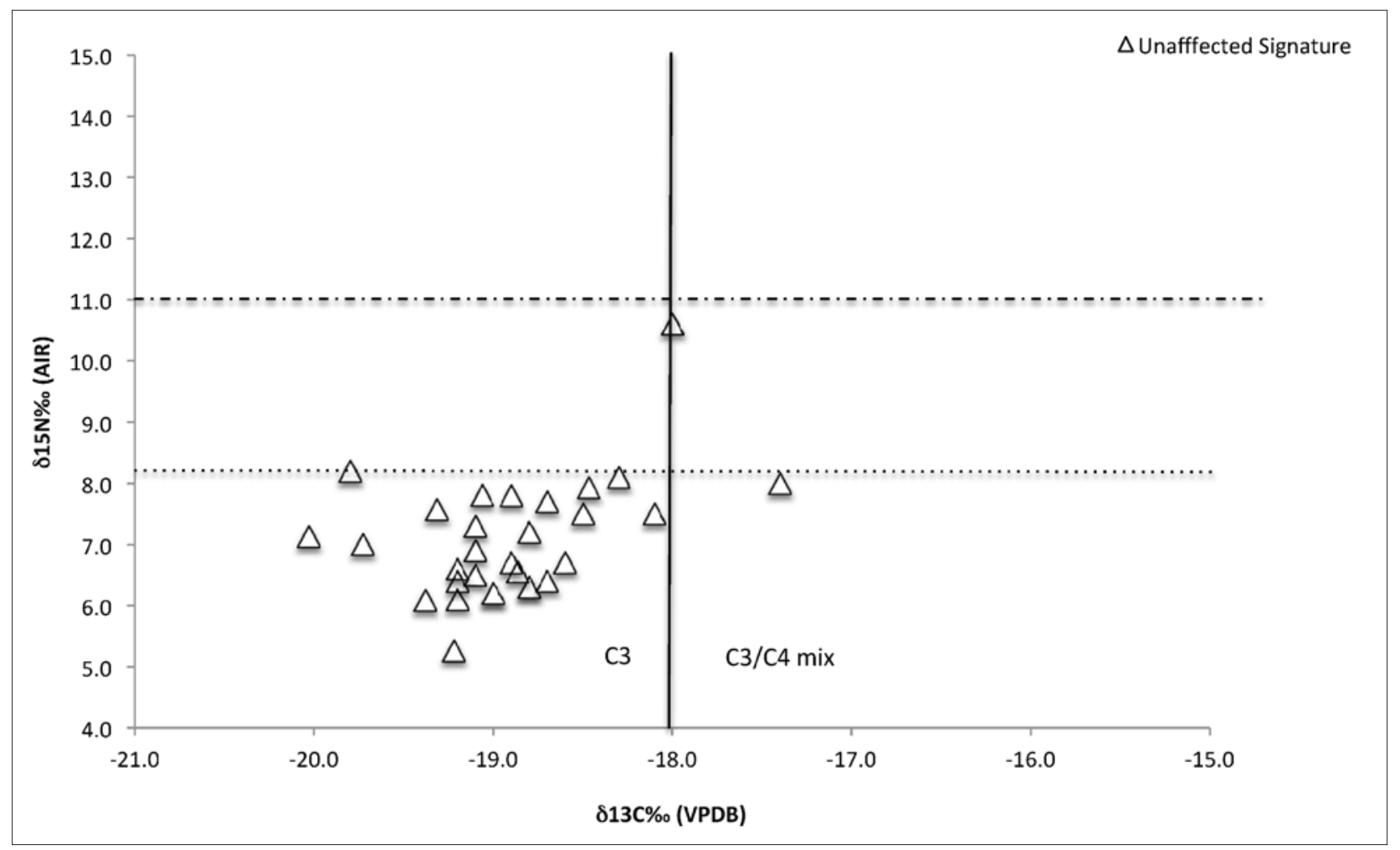

Fig. 7. The unaffected dietary signature of caprines on the Konya plain. 


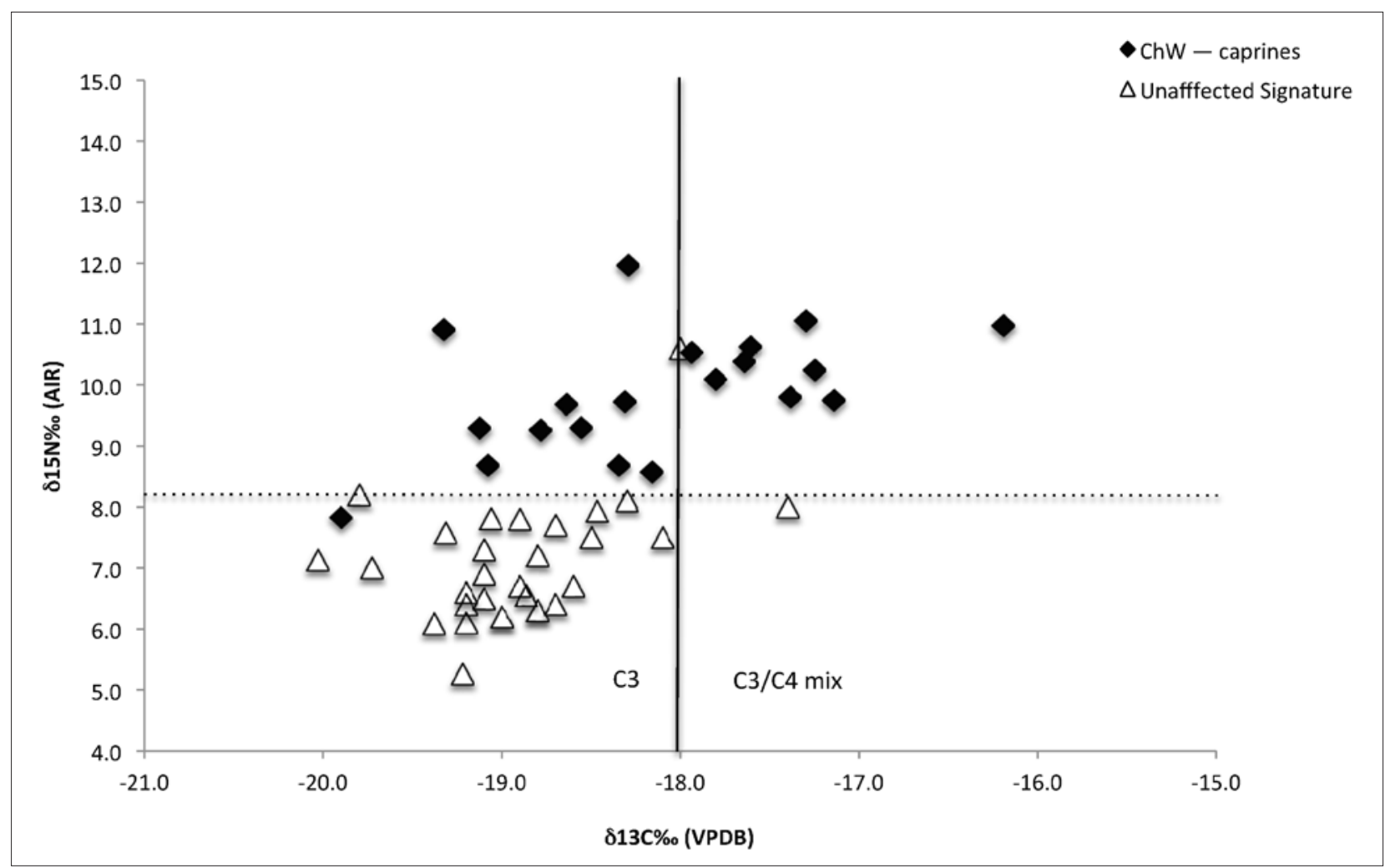

Fig. 8. Caprines from Çatalhöyük West, where the caprines are morphologically and demographically domestic (affected signature), plotted against the unaffected caprine signature. ChW= Çatalhöyük West.

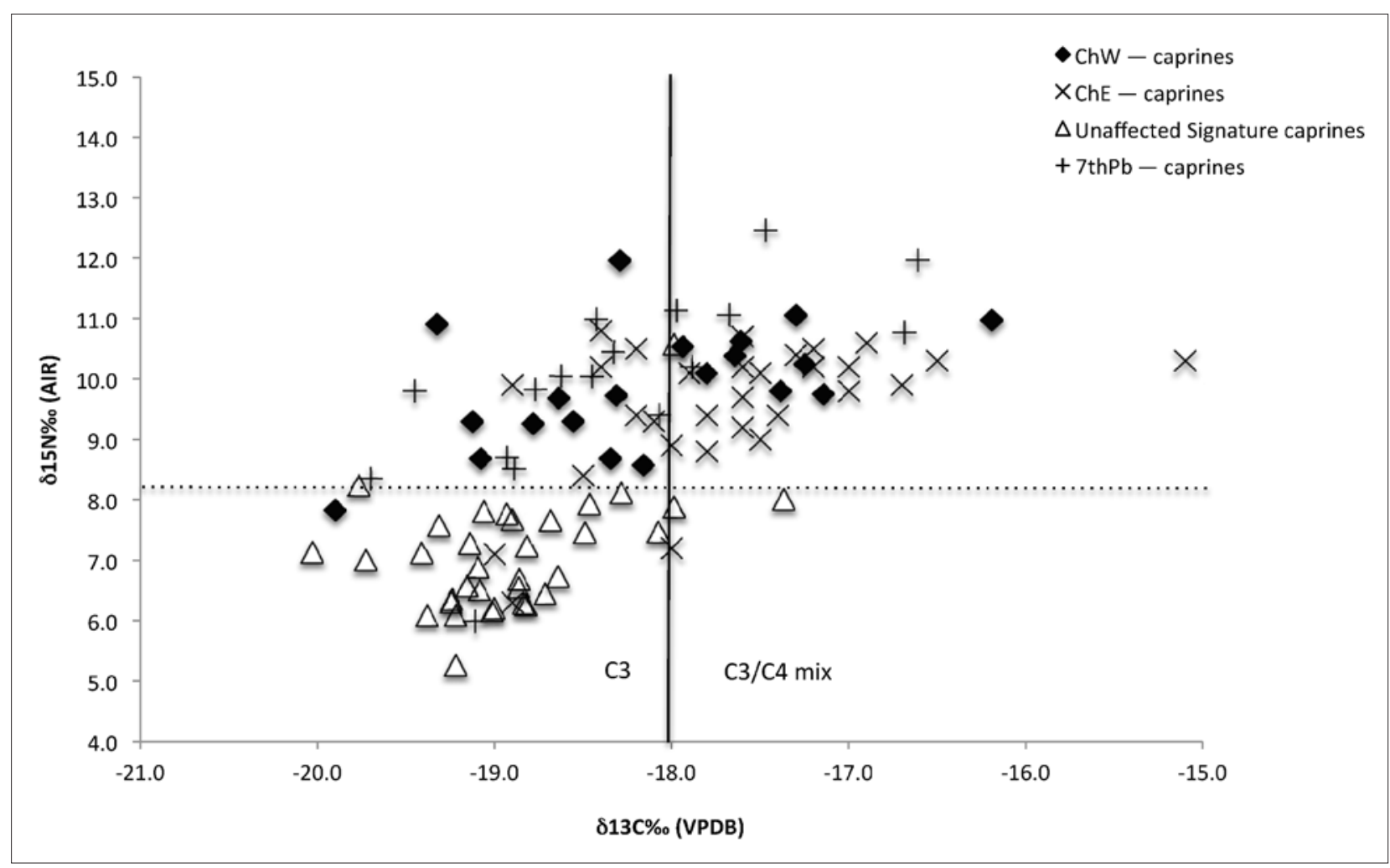

Fig. 9. Caprines from Çatalhöyük West, Çatalhöyük East and seventh-millennium Pınarbaşı, where caprines are considered to be morphologically and demographically domestic, plotted against the unaffected signature for caprines. ChE = Çatalhöyük East; 7thPb = seventh-millennium Pınarbaşı; ChW= Çatalhöyük West. 
summer temperatures or onto grazing areas with pastures fed by groundwater from various sources. Changes seem to have occurred over time. Initially, as well as pasturing sheep year round on the Konya plain, some were herded year round in sheltered valley locations, perhaps in the foothills or hollows on the fan. Over time, more sheep were pastured year round on the Konya plain, though the data from later archaeological levels demonstrate a return to some being herded in more sheltered locations as witnessed in the earliest archaeological levels. A small, but constant number were, throughout the lifetime of the site, herded either around karstic springs or taken on summer transhumance.

The extent to which caprines were moved through the landscape can be tracked via the plant material found in their dung. At Çatalhöyük the evidence from dung-fuel remains suggests that crop by-products were used as animal fodder or as a dung additive to improve dung-fuel quality, or both (Fairbairn et al. 2005: 173). Analysis of the plant remains in the dung suggests that caprines were pastured in relatively wet areas throughout late spring to late summer; grazing is assumed because some of the plants represented are relatively small and impractical to collect in bulk. Several taxa (Aeluropus, Sporobolus and Crypsis), all of which are saline-loving $\mathrm{C}_{4}$ plants, have been identified in the dung; their presence could help explain the increased levels of $\mathrm{C}_{4}$ and nitrogen in the affected caprine signature seen at Çatalhöyük (Bogaard et al. 2013). Spring or early summer grazing is also supported by phytolith analysis. Phytoliths found in dung imply off-site grazing on wild grasses and woody herbaceous plants, probably, according to A.M. Rosen (2005), grazing on autumn and winter vegetation, either before or after the grasses had flowered. It is possible that these caprines were being pastured away from the site, perhaps at a satellite-herding site such as seventh-millennium Pınarbaşı.

Dental microwear analysis suggests that the majority of sheep at Çatalhöyük ate graze that probably included dry, mature grasses, hay fodder, cereal stubble or cereal fodder. Some most likely grazed on winter pastures or wetland edge grasses, reeds or sedges (Henton 2013). It is worth noting that the dental microwear analysis indicates a dominance of $\mathrm{C}_{3}$ fibre-rich elements, with $\mathrm{C}_{4}$ fibre-rich elements contributing only a small component of the diet. The inclusion of $\mathrm{C}_{4}$ plants, as indicated by the carbon isotopes, could be the result of foddering. It could also be the result of moving caprines away from their natural habitat and onto the steppe/wetland mosaic and riverine areas of the plain and marshy areas with $\mathrm{C}_{4}$ marsh plants. These areas would be closer to human habitation than the hill zones, and therefore easier to access and control. The change in nitrogen is interesting and could be the result of changes in diet: salinity, aridity and manuring can all increase $\delta^{15} \mathrm{~N}$ levels in plants, increases that would then be passed onto the consumer. But it is also possible that these increases are the result of direct action on the animal. In other words, something the animal experienced induced raised $\delta^{15} \mathrm{~N}$ levels. Possibilities include some sort of stress, perhaps due to reduced access to water, impoverished conditions, lack of food or overcrowding. However, until more work is done on changes in nitrogen ratios and animal physiology it is not possible to identify the precise reasons for the increase. Furthermore, it is likely that the increased $\delta^{15} \mathrm{~N}$ levels are the result of several contributing factors rather than a single cause.

\section{Sites with early herding?}

Having established the existence of a distinguishable difference between the dietary signature for wild caprines and that of known domestic caprines, it should now be possible to start interpreting results from sites where the early herding of caprines is suspected and/or the 'domesticated' status is questionable.

Chronologically, the first of these is Boncuklu, where caprines comprise $4.9 \%$ of the identified species (Baird et al. 2012: 229). Of these, only six samples were suitable for isotope analysis: three of these fall within the unaffected range, one lies just outside this range and two have remarkably high $\delta^{15} \mathrm{~N}$ levels (fig. 10). If, for a moment, the outliers are ignored, the consistency between the caprines at Epipalaeolithic and ninth-millennium Pınarbaşı can be seen to continue through to Boncuklu, suggesting that some of the Boncuklu caprines consumed the same diet as the unaffected caprines of the Epipalaeolithic and ninth millennium cal. BC. It seems reasonable to conclude, therefore, that the diet of these animals was not affected by human intervention.

The Boncuklu outliers with enriched nitrogen tell a different story. The results from the caprines at Epipalaeolithic Pınarbaşı threw up one anomaly: a sample with higher levels of $\delta^{15} \mathrm{~N}$ than any of the other caprines, but still below $11 \%$ - a level of $\delta^{15} \mathrm{~N}$ held to be significant with regard to unaffected fauna on the Konya plain (see above). Knowledge of the local flora and environment suggests that the high levels of $\delta^{15} \mathrm{~N}$ seen in the Epipalaeolithic anomaly could be explained by the consumption of saline marsh plants that grow on the plain. However, while this could help explain the Boncuklu sample with a $\delta^{15} \mathrm{~N}$ level of $8.6 \%$, it cannot, necessarily, be used for the two anomalies with $\delta^{15} \mathrm{~N}$ levels of over $13 \%$; no wild/unaffected individual from the Konya plain has $\delta^{15} \mathrm{~N}$ levels of more than $11 \%$. It is, therefore, highly unlikely that the two caprines with $\delta^{15} \mathrm{~N}$ levels of over $13 \%$ consumed a totally natural or unaffected diet as found on the Konya plain. 


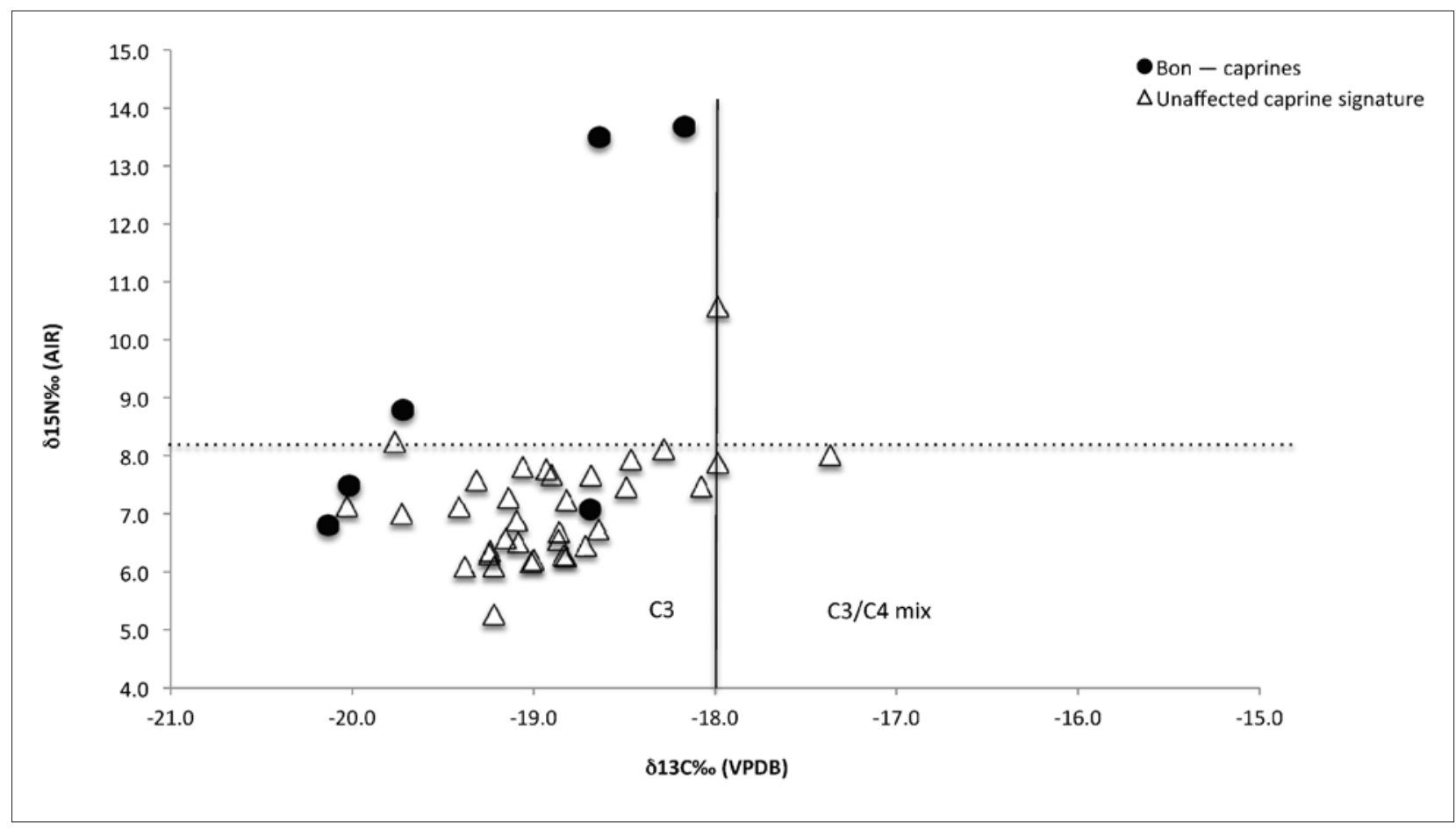

Fig. 10. Caprines from Boncuklu plotted against the unaffected signature (Epipalaeolithic Pınarbaşı and ninth-millennium Pınarbaşı). Bon = Boncuklu.

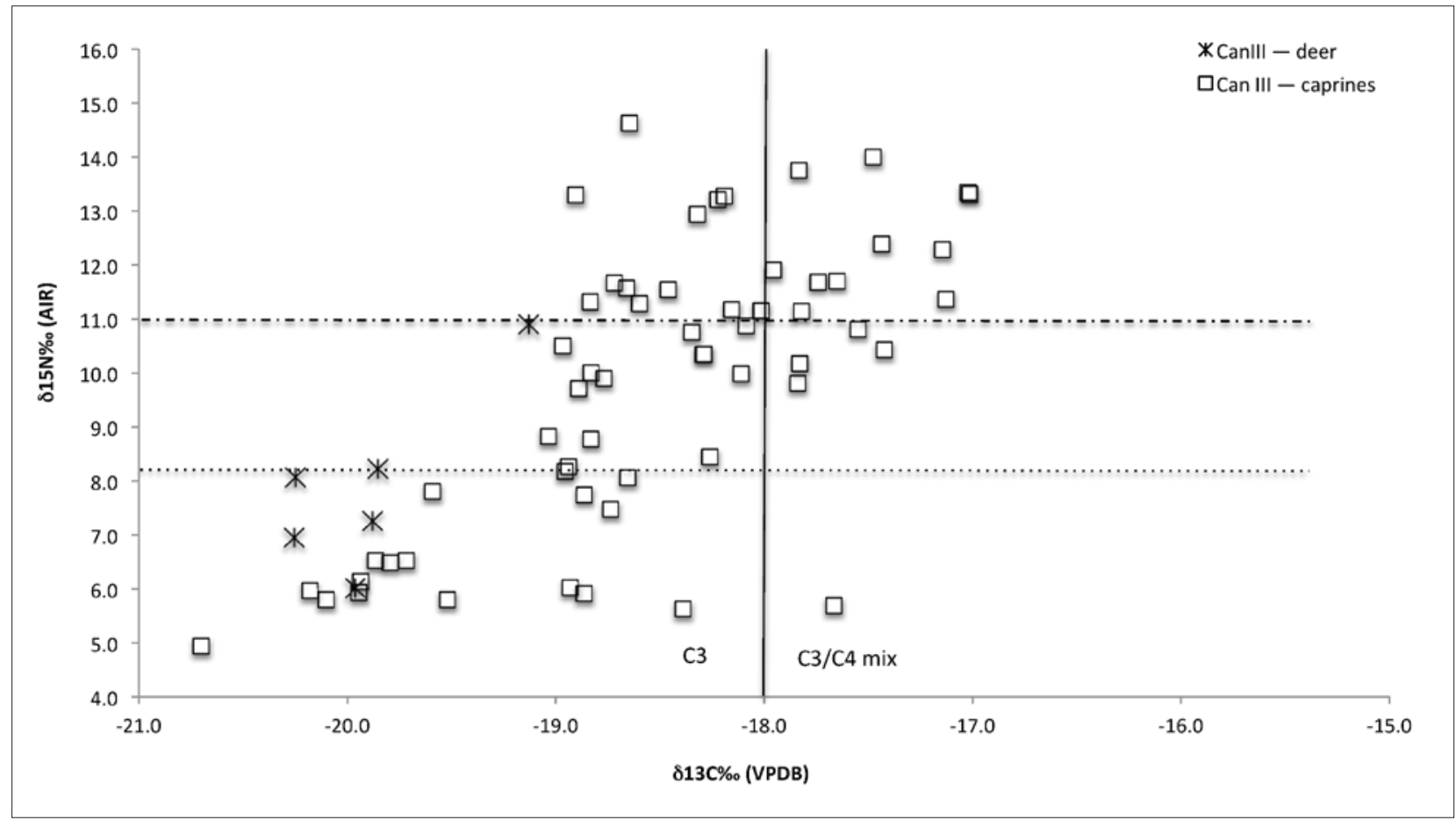

Fig. 11. The caprines and deer from Canhasan III. CanIII = Canhasan III.

The Canhasan III sequence apparently commences approximately 100-200 years after the end of the Boncuklu sequence (as represented by preserved in situ material at Boncuklu - we cannot exclude the possibility of an overlap between the latest occupation at Boncuklu and the earliest occupation at Canhasan III). Although full understanding of the Canhasan III site is hampered by a lack of published data and analysis, the preliminary assessment of the animal bones suggests that caprines were 'fairly common' (Payne in French et al. 1972: 188). Prior to this, caprines do not appear to have been of much economic importance on the Konya plain. 
The first thing to notice, as shown in figure 11, is that the spread of results is far greater than at any of the earlier sites. The second is that a significant proportion of the caprines falls outside the unaffected diet range. The differences in caprine $\delta^{15} \mathrm{~N}$ levels are, probably, the result of human intervention, with some of the caprines being wild, while others were manipulated/managed. Since this extensive range of nitrogen values comes from one site and from within a relatively restricted chronological period, the differences are unlikely to reflect climatic or environmental change between earlier and later parts of the overall sequence.

Figure 12 shows the unaffected caprine diet plotted against caprines from Canhasan III. This seems to confirm the initial impression that both affected and unaffected caprines were part of the economy at Canhasan III.

Where did the affected caprines found at Canhasan III come from? Were they introduced to the Konya plain as herded animals or were they brought under human control in the locality? As noted above, the presence of 'managed' sheep has been argued for the site of Aşı1klı Höyük by level 4, ca 8,200 cal. BC (Stiner et al. 2014). Work undertaken by H. Buitenhuis (1997) suggests, based on demographics and the presence of perinatal animals, that managed caprines were present at the site by level 2, ca 7,800-7,600 cal. BC. Given that Canhasan III closely postdates Aşıklı Höyük, it is possible that herded caprines were introduced onto the Konya plain from Cappadocia, either immediately preceding or early in the occupation of Canhasan III.
However, as shown in figure 13, when plotted against the caprines from Canhasan III the two caprine outliers with high $\delta^{15} \mathrm{~N}$ levels from Boncuklu no longer appear as outliers. Given the claims for Aşıklı Höyük, it is not inconceivable that some sort of 'management' was also taking place at Boncuklu - a site contemporary with Aşıklı Höyük. Given the presence of small amounts of herbivore dung at Boncuklu (Wendy Matthews, personal communication August 2013) and the elevated $\delta^{15} \mathrm{~N}$ levels, it is possible that the two outliers from Boncuklu could be early herded caprines. Furthermore, since Canhasan III postdates Boncuklu, it is possible that caprine herding on the Konya plain expanded during the interim and what we see at Canhasan III is a continuation of practices begun at Boncuklu. The archaeobotancial evidence from Boncuklu suggests that the community was beginning to practice small-scale cultivation (Baird et al. 2012). It is possible that what we are seeing is the beginning of caprine herding.

The very high $\delta^{15} \mathrm{~N}$ levels seen at Boncuklu and Canhasan III do not occur at the later sites: Çatalhöyük East, seventh-millennium Pınarbaşı and Çatalhöyük West (see figure 14). It is possible that the high $\delta^{15} \mathrm{~N}$ levels are the result of unknown factors relating to stress, perhaps brought on through unintentional mismanagement. If the high $\delta^{15} \mathrm{~N}$ levels relate to stress, we might expect this to be a more common phenomenon among the earliest affected caprines and that, with experience, the slightly later sites had alleviated such conditions.

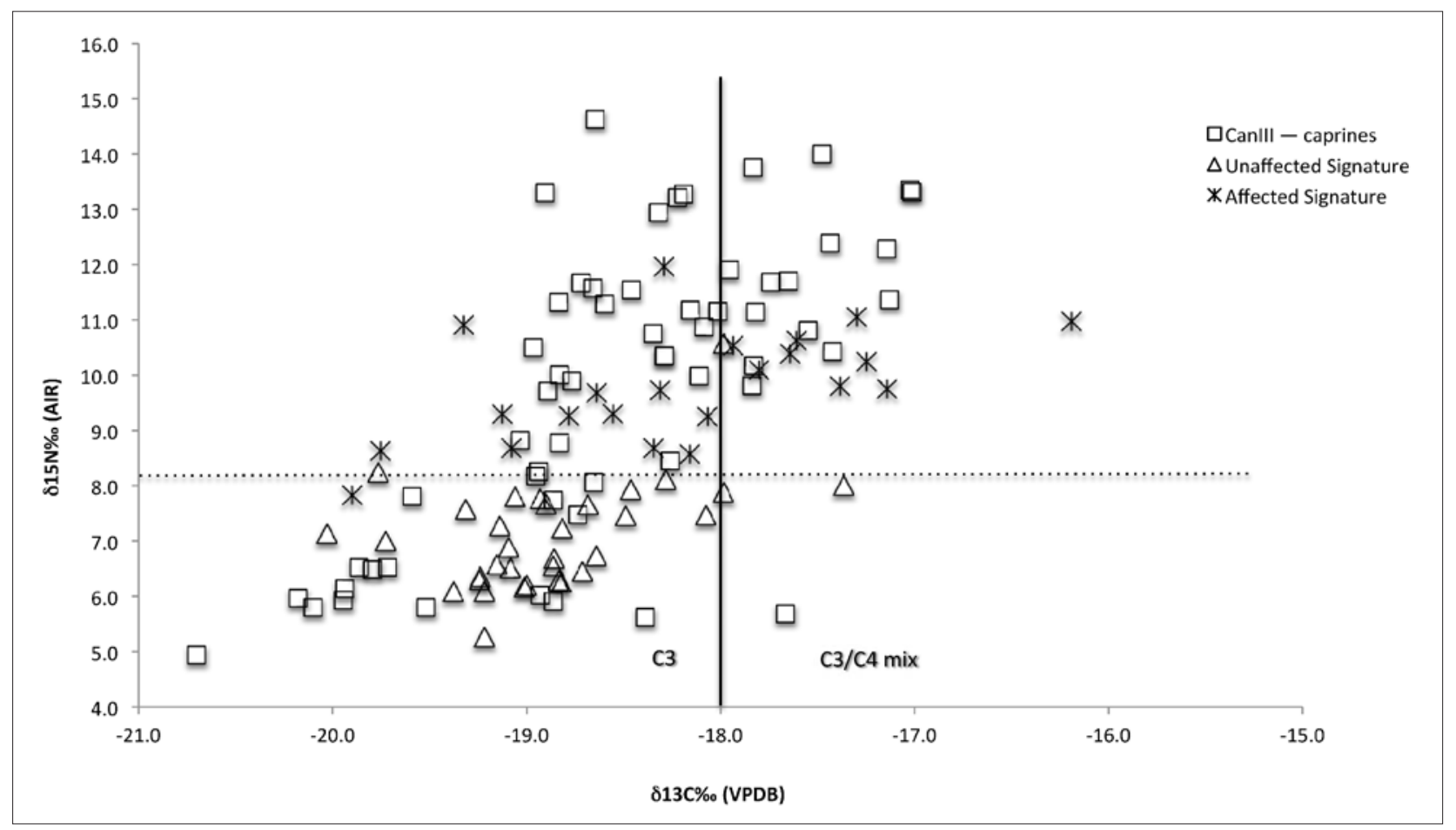

Fig. 12. Caprines from Canhasan III plotted against the unaffected signature and the domesticlaffected caprines from Çatalhöyük West. Can III = Canhasan III. 


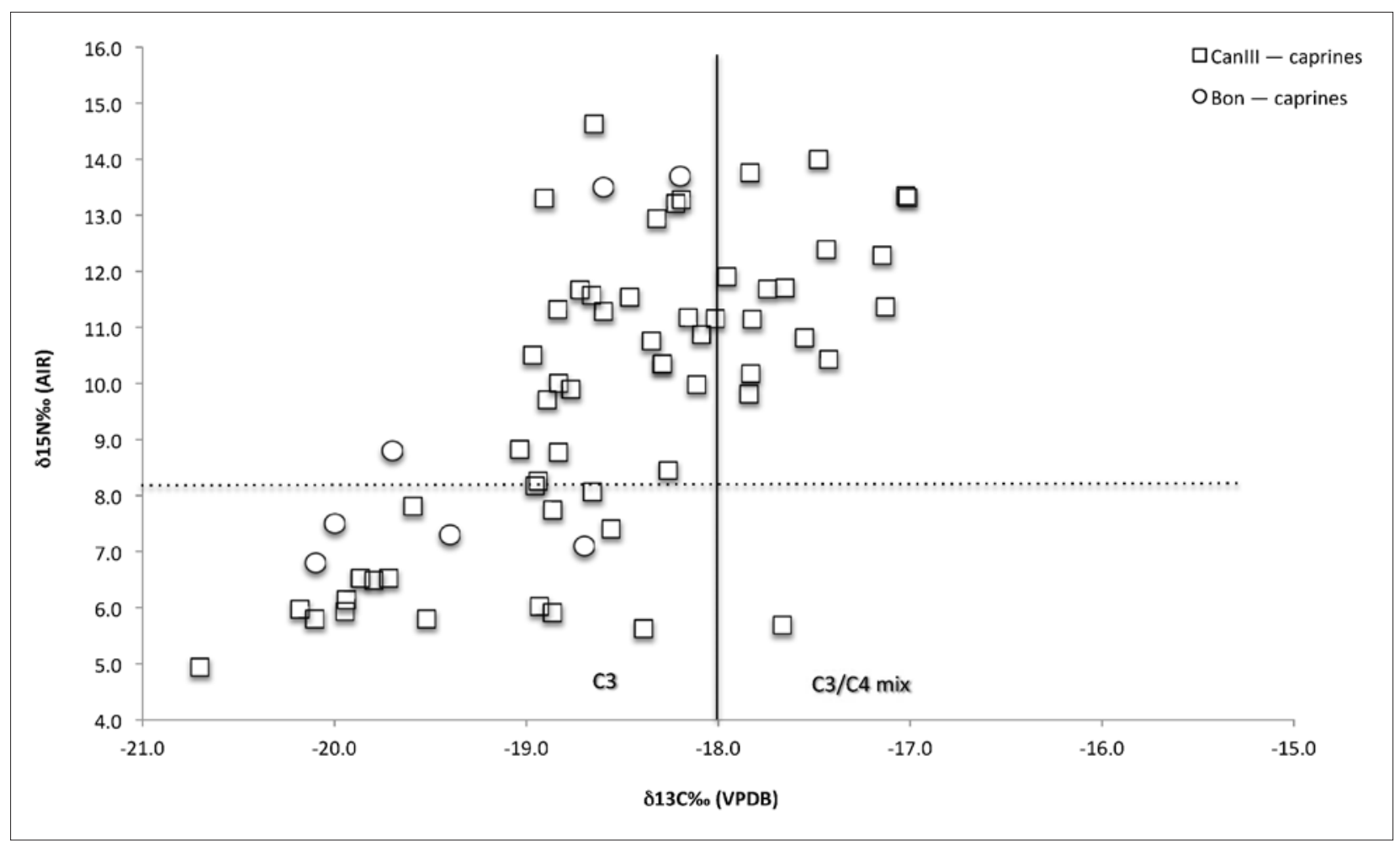

Fig. 13. Caprine dietary signatures from Boncuklu plotted against those from Canhasan III. Bon= Boncuklu; CanIII= Canhasan III.

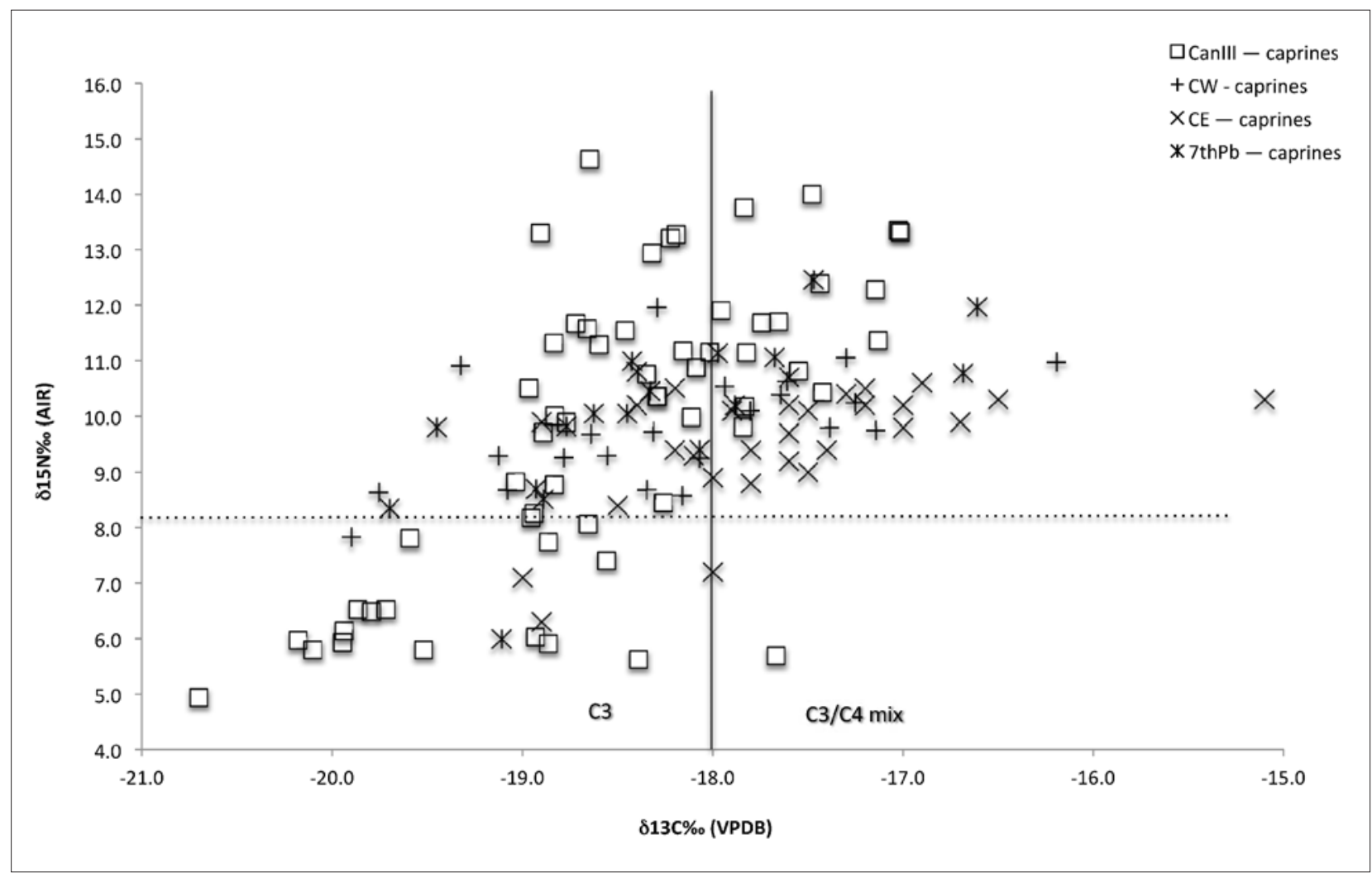

Fig. 14. The caprines from Canhasan III plotted against those from the later sites of Çatalhöyük West, Çatalhöyük East and seventh-millennium Pinarbass. It is noticeable that caprines from Canhasan III have higher $\delta^{15} \mathrm{~N}$ levels than those of the later sites. CanIII = Canhasan III; ChE = Çatalhöyük East; 7 thPb $=$ seventh-millennium Pinarbaşl; $C h W=$ Çatalhöyük West. 


\section{Conclusions}

The aim of this research was to try to document, through changes in caprine diet, the very earliest caprine management strategies in central Anatolia: the seven case-study sites provide a unique opportunity to consider diet over a ca 8,500-year period - covering the appearance of domestic caprines on the Konya plain - within a restricted geographic and environmental location.

The carbon and nitrogen isotope results from the caprines, combined with the $\mathrm{C}_{3} / \mathrm{C}_{4}$ baseline provided by the carbonised plants from Çatalhöyük East, offer a dietary signature for wild caprines unaffected by human intervention living on the Konya plain. Using the same technique, a dietary signature for caprines significantly affected by human management has also been established.

Working with established zooarchaeological methodologies, the earliest evidence for morphologically domesticated caprines on the Konya plain comes from Çatalhöyük East and is dated to ca 7,100 cal. BC. When working with dietary signatures, the results indicate the presence, in significant numbers, of both caprines consuming 'unaffected' diets and caprines consuming 'affected' diets at Canhasan III; it seems that there are significant quantities of both 'wild' and 'managed' caprines at the site or, possibly, just managed caprines, some of whom consumed a largely wild-type diet. At Boncuklu, while very few caprines have been found, of the six sampled, three (50\%) fall outside the 'unaffected' signature range, suggesting the possibility of 'managed' caprines as early as ca 8,300 cal. BC on the Konya plain.

The similarity between the affected caprines from Boncuklu and Canhasan III is striking and raises the possibility that these animals came from the same or very similar locales, or were managed in a similar manner. What is particularly intriguing about Boncuklu is the potential presence of 'managed' caprines at a site where caprines appear to have been of little economic importance.

Given that there is evidence to support the adoption and adaption of modest-scale cultivation on the Konya plain wetland/steppe area by the Boncuklu community (Baird et al. 2012), the earliest farming evidenced on the plain, the data from Boncuklu seem to suggest that small-scale cultivation and herding may have appeared simultaneously on the Konya plain. The likely absence of wild cultivars within central Anatolia argues for the introduction of domesticated plants (Baird et al. 2012; 2013). With regard to herding, however, there are two possible scenarios: that the practice of herding was transferred to the Konya plain via the wellestablished, long-distance networks that existed between the Levant and Anatolia (Baird et al. 2012), where the presence of wild caprines allowed in situ experimentation with local animals, or that small numbers of herded caprines were physically transported to the Konya plain, thereby providing the Boncuklu community with the necessary elements to start small-scale mixed farming. In either case, it is important to appreciate that mixed farming could begin within the context of low-level food production, with farming making a very limited dietary contribution for several centuries, and that herding is not necessarily only associated with largescale cultivation. In this context, experimentation with plant and animal management might be seen as going hand in hand: a rather different scenario from that proposed for the Levant, where significant levels of cultivation preceded animal management (Asouti, Fuller 2012).

Over the years there have been many attempts to try to explain why humans decided to domesticate plants and animals. Traditionally there has been a tendency to try to fit explanations into one of three categories: environmental change, population pressure or cultural change. In actuality many of the theories put forward span two, if not all three of these categories. From early on researchers have looked for a reason that would 'persuade a hunter-gatherer to modify his subsistence pattern significantly' and adopt agriculture (Flannery 1969: 75).

Advocates of environmental change include V. Gordon Childe (1928; 1936; 1942), who argues that the increasing warmth and dryness of the Pleistocene would have brought plants, animals and humans together in constrained zones near water, and, in order to compete successfully for the reduced resources, humans would have been compelled to domesticate and control both animals and plants. The cooling nature of the Younger Dryas has also been interpreted as pivotal to the adoption of domesticates, as it could have forced some human societies to diversify into new modes of subsistence (Moore, Hillman 1992; Baruch, Bottema 1999; Grossman, Belfer-Cohen 2002; Henry 2002; Harris 2003; Bettinger et al. 2007).

Although there is little doubt that the increase in rainfall and temperature that followed the Late Glacial Maximum played a part in the emergence of the less mobile and more territorially focused Early Natufian subsistence strategies, it is worth noting that, when faced with the abrupt climate changes of the Younger Dryas (ca $10,750-9,650$ cal. BC) - a worldwide phenomenon that saw a global return to near glacial conditions - the increasingly sedentary hunting and gathering communities of the Early Natufian did not domesticate plants and animals. Instead, responses to the changing climate varied from region to region. In the southern Levant, communities returned to a more mobile way of life, continuing to exploit a similar range of wild resources as they had hitherto (Munro 2004), while in the Middle and Upper Euphrates valley and the Zagros, societies maintained relatively sedentary settlements and stable resource catchment zones (Boyd 2005). There is no compelling evidence for the adoption of agriculture and herding during this climatically 
adverse time, which would suggest that these conditions were not the driving factor behind agriculture and herding.

P.J. Richerson and colleagues (2001) argue that it was the climatic amelioration of the Early Holocene, coupled with an accompanying rise in $\mathrm{CO}_{2}$ that made agriculture and domestication 'complusory' during the Holocene. They do not see climate as the single driving force, but rather as the 'external' factor that made the adoption of agriculture and herding possible; prior to the Holocene, because of intemperate climatic conditions, including low $\mathrm{CO}_{2}$ concentrations, agriculture per se was not possible (Bettinger et al. 2009). This is an interesting theory that argues for the importance of climate change, but as a positive factor that enables agriculture rather than as a negative one that forces its adoption.

It has also been suggested that population pressure was a driving force, though not necessarily the sole reason, behind domestication, and that the adoption of agriculture and domestication was the result of a 'demand' or a 'push' - an imbalance between populations and resources that forced people to consider radical solutions to solve their nutritional imbalance (Cohen 1977; 2009; Bellwood 2009). P.M. Lambert (2009), however, argues that an increasing population could have been a 'pull' factor rather than a 'push' factor: agriculture might have emerged and spread as a behavourial strategy that enhanced reproduction, as opposed to agriculture being the result of burgeoning populations fuelling a need for increased productivity. Given the difficulty of assessing population increase and decrease in prehistory (Price, Bar-Yosef 2011), the precise impact of population pressure as a driving force behind the adoption of agriculture remains a moot point. Presumably populations had fluctuated prior to the Younger Dryas and had adjusted and adapted without the need to embrace cultivation and herding, despite the presence in some areas of suitable species to domesticate.

Although not as popular as population pressure or environmental change, social and cultural changes have also been mooted as possible drivers behind domestication. Thus J. Cauvin (2000) argues that the most important changes allied to the emergence of agriculture and domestication are cultural rather than economic: the transition to farming involved concepts and ideas as much as, or more than, the production of food.

Some researchers, attempting to distinguish between social and biological domestication, have argued that animals are, in essence, 'domesticated' when they become property (Ducos 1978; Ingold 1980). Under this definition the key change in animal domestication lies, as noted by Nerissa Russell (2012: 213), not in animals' bodies, but in the social definition of animals as a resource: wild animals are shared, whereas domestic animals are husbanded by their owners. Others have picked up on a ritual theme; for example, J. Peters and colleagues (1999) suggest that animals, particularly cattle and sheep, were initially domesticated for use as sacrifices. B. Bender (1978), however, sees the beginnings of herding as a social adjunct whereby hunter-gatherers domesticated a few prized specimens that were then used to fund social exchange, feasting, etc. The idea that feasting provided the impetus for both plant and animal domestication has been developed by B. Hayden (1990; 1992; 1995; 1996; 2001; 2003; 2009), who argues that people chose to develop agriculture in areas of plenty, in order to satisfy the desire of the few for "competitive feasting'. It is worth noting, however, that at Çatalhöyük East, although domestic caprines are present in significant numbers, it is wild aurochsen that are found in feasting contexts.

Louise Martin (1999: 101) suggests that the first domesticated caprines brought into eastern Jordan may have had a role beyond that of subsistence: use as status objects. Being novel and desirable, they could have been utilised as exchange goods or gifts, playing a part in the forging and maintenance of alliances and other social relationships. It is also possible, as mooted by J.-D. Vigne and D. Helmer (2007), that the desire for milk was a prime reason behind the initial domestication of ungulates, particularly caprines. However, the evidence for this is relatively insubstantial and, although it is possible that milking occurred very rapidly following domestication, especially of caprines, it is unlikely to have been the main driving force. Common to many of the social/ritual explanations regarding the origins of domestication is the presumption that a certain level of human social organisation must be reached before animal domestication becomes feasible (Hole 1996: 263; Tchernov in Horwitz et al. 1999: 65; Peters et al 1999).

Recently, evolutionary ecologists have proposed theories designed to explain the adoption of agriculture and herding. Evolutionary ecology developed out of an earlier perspective known as cultural ecology. Using culture as the primary mechanism of adaption, cultural ecology focuses on the dynamic relationship between human society and its environment (Price, Bar-Yosef 2011: S167). Considerable emphasis is placed on the ability of humans to reason and optimise their behaviour; natural selection is seen to operate in relation to the behaviour of individuals. The assumption is that natural selection means organisms adapt to local conditions in fitness-enhancing or optimising ways (Gremillion, Piperno 2009; Winterhalder, Kennett 2009). Out of this perspective comes a concept called the optimal foraging theory (OFT). The OFT argues that the most efficient foraging strategies produce the greatest return in energy relative to the time and effort expended. Optimal foraging assumes that humans make rational decisions based on economic efficiency (Price, Bar-Yosef 2011: S167-68). 
To conclude, it seems that initially the tendency of scholars was to see the move from hunter-gatherer to farmer as something radical, sudden, relatively uniform (the farming package) and very definitely desirable: a change motivated by external forces that pushed huntergatherers towards agriculture and herding. It appears, however, that the process was far more fluid and gradual than this; the change from hunter-gatherer to farmer occurred in different places at different times, in different ways and potentially for different reasons.

For a long time domestication has been seen as the inevitable conclusion of a linear pathway that passed through stages of ever-increasing complexity: from 'sedentism' to 'sedentism plus agriculture' to 'sedentism plus agriculture plus herding' (Redding 2005: 45; also Wasse 2001). Irrespective of the catalyst, the tendency until quite recently has been to see the process of domestication as a sequential development or 'next step'. The results of this research, however, support the argument that the beginnings of domestication were prompted by 'rapidity of change, fluctuating environmental conditions and random forces' (Wasse 2001: 22-23). Herding should not be seen as an inevitable progression; it appears instead to be the result of coinciding circumstances or needs. It is likely that not only was the domestication process different for each species, but also that it varied within species, depending upon the needs and characteristics of the individuals and communities involved.

Looking at the evidence from the Konya plain, the community at Boncuklu began to embrace both cultivation and herding - albeit on a small scale - while that at ninthmillennium Pınarbaş1, which overlaps chronologically with Boncuklu, maintained a broad-spectrum diet and hunter-gatherer lifestyle. This, along with the fact that it potentially took several hundred years for caprine herding to become established on the Konya plain, suggests that the adoption of cultivation and herding was a slow process, and that for several centuries the early herding of caprines took place alongside more traditional economic practices. Given that wild species appear to remain abundant at both Boncuklu and Canhasan III, it is unlikely that over-hunting led to the adoption of herding/farming on the Konya plain.

In addition, there are interesting implications regarding the time taken to switch from the very small-scale herding seen at Boncuklu to the evidence from Canhasan III where caprines form a significant part of the faunal assemblage, with over $50 \%$ of them displaying an affected diet. The gap between the main bodies of evidence from Boncuklu and Canhasan III, which suggests a gradual uptake, runs counter to the theory that cultivation and herding, once introduced, were rapidly adopted by communities. Such a time delay also makes it seem less likely that 'push' factors, such as population pressure or deteriorating environment and climate change, forced the adoption of agriculture. If, as argued by M.N. Cohen (2009) and P. Bellwood (2009), population increase and pressure 'pushed' communities towards agriculture, it might be expected that the adoption of herding would have occurred somewhat quicker than the several centuries potentially witnessed on the Konya plain, and, moreover, that it would have been more uniformly adopted across a landscape. The evidence from the Konya plain clearly shows an ad hoc, pick-and-mix approach to the adoption of cultivation and herding; communities appear to have chosen to adopt agriculture, as opposed to being pressured into it. The same arguments can be used with regard to climate change and changing environments; it is unlikely that the adoption of domesticates would have been so extended, or so variable between neighbouring sites (compare Boncuklu and ninth-millennium Pınarbaşı), had deteriorating environmental conditions 'pushed' communities towards alternative lifestyles.

The Neolithisation of Anatolia has often been presented as an offshoot of that of the Fertile Crescent: the result of colonisation by groups from other regions. However, the evidence of early caprine herding at Boncuklu adds credence to the premise that the early farming communities living in Anatolia were in fact indigenous populations that adopted cultivation and herding, rather than in-coming agriculturalists who established themselves in the region. It is, of course, possible that the indigenous populations of central Anatolia who first engaged in the manipulation of caprines, as seen in the dietary evidence, were, as Doug Baird and colleagues (2012) suggest, influenced by contact with agriculturalists from the Fertile Crescent. It seems that on the Konya plain the adoption of farming was a slow, organic process, which responded to local conditions and factors, and developed and adapted to the needs and requirements of the local community.

In summary, when used with care, carbon and nitrogen dietary signatures can help to identify the very earliest human management of animals. By applying this methodology to seven sites located within a restricted geographical area and covering a significant chronological time frame it has been possible to identify and chart very early changes in human/animal relationships, changes that would not have been possible to identify using the more traditional techniques associated with zooarchaeology.

\section{Acknowledgements}

This research was funded by the Arts and Humanities Research Council and the Natural Environment Research Council (NERC) Isotope Geosciences Facilities Steering Committee. Particular thanks go to Angela Lamb (NERC) for her help and advice with regard to the stable isotope analysis. Ian Hodder, Peter Biehl and David French allowed me access to the Çatalhöyük East, Çatalhöyük West and Canhasan III material, respectively - thank you. 


\section{Appendix A}

The following tables detail the isotope data from each site.

\section{Epipalaeolithic Pınarbaşı}

\begin{tabular}{|c|c|c|c|c|c|}
\hline Lab no. & $\delta^{13} \mathrm{C}$ & $\delta^{15} N$ & $C: N$ & Species & Element \\
\hline PB5002 & -19.14 & 7.28 & 3.2 & Ovis/Capra & Scapula \\
\hline PB5007 & -19.01 & 6.17 & 3.5 & Capra? & Radius \\
\hline PB5010 & -18.64 & 6.73 & 3.2 & Ovis & Metacarpal \\
\hline PB5017 & -18.71 & 6.45 & 3.3 & Ovis & 1st phalanx \\
\hline PB5018 & -19.22 & 6.09 & 3.3 & Ovis/Capra & 1st phalanx \\
\hline PB5019 & -19.24 & 6.36 & 3.4 & Ovis/Capra & Metatarsal \\
\hline PB5020 & -18.08 & 7.47 & 3.5 & Ovis/Capra & Metapodial \\
\hline PB5022 & -17.99 & 10.57 & 3.3 & Ovis/Capra & Pelvis \\
\hline PB5024 & -17.37 & 8.01 & 3.5 & Ovis/Capra & Radius \\
\hline PB5025 & -18.93 & 7.77 & 3.3 & Capra & Ulna \\
\hline PB5026 & -18.29 & 8.11 & 3.5 & Ovis/Capra & Femur \\
\hline PB5027 & -18.84 & 6.29 & 3.4 & Capra & 2nd phalanx \\
\hline PB5028 & -18.49 & 7.46 & 3.3 & Capra & Metatarsal \\
\hline PB5034 & -18.82 & 6.26 & 3.3 & Ovis/Capra & 1st phalanx \\
\hline PB5035 & -19.09 & 6.51 & 3.5 & Ovis/Capra & Tibia \\
\hline PB5036 & -19.77 & 8.24 & 3.3 & Ovis/Capra & Phalanx \\
\hline PB5041 & -18.69 & 7.66 & 3.3 & Ovis & 2nd phalanx \\
\hline PB5044 & -19.16 & 6.58 & 3.4 & Ovis/Capra & Carpal/tarsal \\
\hline PB5061 & -19.09 & 6.89 & 3.4 & Ovis/Capra & Phalanx \\
\hline PB5080 & -17.87 & 8.30 & 3.3 & Lepus & Metapodial \\
\hline PB5081 & -18.86 & 6.69 & 3.2 & Capra & 3rd phalanx \\
\hline PB5099 & -18.82 & 7.23 & 3.1 & Ovis/Capra & Carpal \\
\hline PB5100 & -19.00 & 6.20 & 3.1 & Ovis/Capra & Metapodial \\
\hline
\end{tabular}

Ninth-millennium Pınarbaşı

\begin{tabular}{llllll} 
Lab no. & $\delta^{13} C$ & $\delta^{15} N$ & C:N & Species & Element \\
\hline PB5005 & -19.22 & 5.26 & 3.5 & Ovis/Capra & 4th tarsal \\
PB5011 & -17.99 & 7.88 & 3.5 & Capra & Scapula \\
PB5043 & -19.32 & 7.57 & 3.3 & Ovis/Capra & Metatarsal \\
PB5070 & -19.38 & 6.09 & 3.2 & Ovis/Capra & 1st phalanx \\
PB5074 & -18.86 & 6.55 & 3.5 & Ovis/Capra & 1st phalanx \\
PB5084 & -19.06 & 7.81 & 3.3 & Ovis/Capra & Axis \\
PB5088 & -18.9 & 7.67 & 3.3 & Ovis & Astragulus \\
PB5103 & -18.47 & 7.93 & 3.2 & Ovis/Capra & Tibia \\
PB5104 & -19.73 & 7.00 & 3.1 & Ovis/Capra & Astragulus \\
PB29 & -19.25 & 6.31 & 3.3 & Ovis & n/a
\end{tabular}




\section{Boncuklu}

\begin{tabular}{lcccll} 
Lab no. & $\delta^{13} C$ & $\delta^{15} N$ & C:N & Species & Element \\
\hline BK015 & -20.02 & 7.49 & 3.3 & Capra? & 1 st phalanx \\
BK016 & -20.13 & 6.80 & 3.5 & Ovis/Capra & 1 st phalanx \\
BK018 & -19.45 & 7.32 & 3.3 & Cervid & Metapodial \\
BK020 & -18.69 & 7.08 & 3.3 & Ovis & Calcaneum \\
BK045 & -18.64 & 13.49 & 3.3 & Ovis/Capra & Metapodial \\
BK051 & -19.72 & 8.79 & 3.4 & Ovis? & 2nd phalanx \\
BK064 & -18.17 & 13.68 & 3.2 & Capra & Metatarsal
\end{tabular}

\section{Canhasan III}

\begin{tabular}{|c|c|c|c|c|c|}
\hline Lab no. & $\delta^{13} \mathrm{C}$ & $\delta^{15} N$ & $C: N$ & Species & Element \\
\hline chn002 & -17.84 & 9.81 & 3.3 & Ovis & 1st phalanx \\
\hline chn006 & -17.44 & 12.39 & 3.4 & Ovis & 1st phalanx \\
\hline chn008 & -18.22 & 13.21 & 3.3 & Ovis/Capra & Metatarsal \\
\hline chn010 & -19.72 & 6.52 & 3.3 & Ovis/Capra & Metapodial \\
\hline chn011 & -18.83 & 10.01 & 3.4 & Ovis/Capra & Metapodial \\
\hline chn014 & -17.55 & 10.81 & 3.3 & Ovis/Capra & Metapodial \\
\hline chn015 & -19.59 & 7.81 & 3 & Ovis/Capra & 1st phalanx \\
\hline chn016 & -18.09 & 10.87 & 3.3 & Ovis/Capra & 3rd phalanx \\
\hline chn017 & -19.80 & 6.49 & 3.6 & Ovis/Capra & Metapodial \\
\hline chn018 & -17.67 & 5.69 & 3.3 & Ovis/Capra & Metatarsal \\
\hline chn020 & -18.65 & 14.63 & 3.3 & Ovis & 1st phalanx \\
\hline chn021 & -19.95 & 5.93 & 3.3 & Ovis/Capra & Metapodial \\
\hline chn024 & -18.93 & 6.03 & 3.3 & Ovis/Capra & 1st phalanx \\
\hline chn025 & -17.65 & 11.71 & 3.3 & Ovis/Capra & Metatarsal \\
\hline chn028 & -18.86 & 5.91 & 3.3 & Ovis & 1st phalanx \\
\hline chn029 & -19.87 & 6.52 & 3.3 & Ovis/Capra & Metacarpal \\
\hline chn032 & -18.39 & 5.63 & 3.3 & Capra & 3rd phalanx \\
\hline chn033 & -18.35 & 10.76 & 3.2 & Ovis/Capra & 1st phalanx \\
\hline chn035 & -18.74 & 7.48 & 3.4 & Ovis/Capra & Metatarsal \\
\hline chn036 & -17.82 & 11.14 & 3.4 & Ovis & 1st phalanx \\
\hline chn040 & -18.94 & 8.26 & 3.3 & Ovis/Capra & Metapodial \\
\hline chn045 & -17.83 & 13.76 & 3.4 & Ovis/Capra & Metapodial \\
\hline chn046 & -19.94 & 6.14 & 3.3 & Ovis/Capra & 2nd phalanx \\
\hline chn047 & -18.32 & 12.94 & 3.6 & Ovis/Capra & Metatarsal \\
\hline chn048 & -17.01 & 13.31 & 3.3 & Ovis/Capra & Radius \\
\hline chn052 & -19.03 & 8.82 & 3.4 & Ovis/Capra & Metapodial \\
\hline chn053 & -17.48 & 14.00 & 3.3 & Ovis/Capra & Metapodial \\
\hline
\end{tabular}




\section{Canhasan III (continued)}

\begin{tabular}{|c|c|c|c|c|c|}
\hline Lab no. & $\delta^{13} C$ & $\delta^{15} N$ & $C: N$ & Species & Element \\
\hline chn054 & -17.42 & 10.43 & 3.3 & Ovis/Capra & Metapodial \\
\hline $\operatorname{chn} 058$ & -18.66 & 11.57 & 3.3 & Ovis/Capra & Pelvis \\
\hline $\operatorname{chn} 061$ & -17.96 & 11.91 & 3.5 & Ovis/Capra & Metapodial \\
\hline $\operatorname{chn} 062$ & -18.26 & 8.45 & 3.6 & Ovis/Capra & 1st phalanx \\
\hline chn063 & -17.02 & 13.35 & 3.3 & Ovis/Capra & Metacarpal \\
\hline $\operatorname{chn} 064$ & -17.83 & 10.17 & 3.3 & Ovis/Capra & 1st phalanx \\
\hline chn068 & -18.91 & 13.30 & 3.3 & Ovis/Capra & Femur \\
\hline chn069 & -18.89 & 9.71 & 3.3 & Ovis/Capra & Metapodial \\
\hline $\operatorname{chn} 071$ & -18.97 & 10.50 & 3.3 & Ovis/Capra & Metapodial \\
\hline $\operatorname{chn} 077$ & -18.86 & 7.74 & 3.4 & Ovis/Capra & Humerus \\
\hline $\operatorname{chn} 078$ & -18.46 & 11.54 & 3.4 & Ovis & 1st phalanx \\
\hline chn079 & -18.16 & 11.18 & 3.4 & Ovis/Capra & Metapodial \\
\hline chn080 & -18.95 & 8.18 & 3.3 & Capra? & Metacarpal \\
\hline chn081 & -18.84 & 11.32 & 3.3 & Ovis/Capra & Metapodial \\
\hline $\operatorname{chn} 082$ & -20.70 & 4.94 & 3.3 & Ovis/Capra & 1st phalanx \\
\hline chn085 & -17.13 & 11.37 & 3.3 & Capra? & 2nd phalanx \\
\hline chn089 & -18.66 & 8.06 & 3.3 & Ovis/Capra & 3rd phalanx \\
\hline chn091 & -18.11 & 9.98 & 3.3 & Ovis & 1st phalanx \\
\hline $\operatorname{ch} 104$ & -17.15 & 12.29 & 3.3 & Ovis & 1st phalanx \\
\hline $\operatorname{chn} 105$ & -17.74 & 11.68 & 3.4 & Ovis & 1st phalanx \\
\hline $\operatorname{chn} 107$ & -19.52 & 5.80 & 3.3 & Ovis/Capra & Metapodial \\
\hline chn 108 & -18.29 & 10.35 & 3.3 & Ovis & Ulna \\
\hline $\operatorname{chn} 113$ & -19.85 & 8.22 & 3.3 & Red deer & Radius \\
\hline $\operatorname{chn} 114$ & -18.72 & 11.67 & 3.1 & Ovis/Capra & 1st phalanx \\
\hline $\operatorname{chn} 115$ & -18.60 & 11.29 & 3.4 & Ovis/Capra & Metatarsal \\
\hline $\operatorname{chn} 117$ & -18.77 & 9.90 & 3.3 & Ovis/Capra & 1st phalanx \\
\hline $\operatorname{chn} 120$ & -18.02 & 11.15 & 3.4 & Capra? & 3rd phalanx \\
\hline $\operatorname{chn} 126$ & -18.83 & 8.78 & 3.3 & Ovis/Capra & 2nd phalanx \\
\hline $\operatorname{chn} 130$ & -20.18 & 5.97 & 3.3 & Ovis & Malleolare \\
\hline $\operatorname{chn} 131$ & -19.96 & 6.01 & 3.3 & Red deer & Humerus \\
\hline $\operatorname{chn} 132$ & -18.29 & 10.35 & 3.3 & Ovis/Capra & 1st phalanx \\
\hline $\operatorname{chn} 134$ & -18.19 & 13.28 & 3.4 & Ovis/Capra & 2nd phalanx \\
\hline $\operatorname{chn} 135$ & -20.10 & 5.79 & 3.5 & Ovis & 1st phalanx \\
\hline
\end{tabular}




\section{Çatalhöyük East}

\begin{tabular}{lcclll} 
Lab no. & $\delta^{13} C$ & $\delta^{15} N$ & C:N & Species & Element \\
\hline CH6007 & -16.96 & 11.20 & 3.3 & Ovis & Humerus \\
CH6010 & -17.25 & 12.31 & 3.2 & Ovis & Humerus \\
CH6015 & -17.67 & 11.58 & 3.3 & Capra & 1st phalanx \\
CH6017 & -19.25 & 4.42 & 3.3 & Lepus & Radius \\
CH6019 & -17.32 & 10.69 & 3.3 & Ovis & Radius \\
CH6020 & -18.76 & 6.44 & 3.3 & Lepus & Radius \\
CH6021 & -16.36 & 10.50 & 3.3 & Ovis & Radius \\
CH6028 & -18.44 & 7.99 & 3.3 & Capra & 1st phalanx \\
CH6031 & -19.17 & 7.72 & 3.3 & Ovis & Metapodial \\
CH6036 & -18.36 & 8.77 & 3.2 & Ovis & Humerus \\
CH6046 & -19.21 & 8.02 & 3.3 & Cervid & Humerus \\
CH6049 & -18.23 & 9.82 & 3.4 & Ovis & Femur \\
CH6052 & -19.88 & 7.01 & 3.3 & Cervid & Calcaneum
\end{tabular}

\section{Seventh-millennium Pınarbaşı}

\begin{tabular}{lcccll} 
Lab no. & $\delta^{13} C$ & $\delta^{15} N$ & $C: N$ & Species & Element \\
\hline PB6 & -19.11 & 5.99 & 3.3 & Ovis & n/a \\
PB7 & -19.70 & 8.35 & 3.3 & Ovis & n/a \\
PB8 & -17.68 & 11.06 & 3.3 & Ovis & n/a \\
PB9 & -18.43 & 10.99 & 3.4 & Ovis & n/a \\
PB10 & -18.33 & 10.45 & 3.25 & Ovis & n/a \\
PB11 & -19.45 & 9.81 & 3.3 & Ovis & n/a \\
PB12 & -18.93 & 8.70 & 3.25 & Ovis & n/a \\
PB13 & -17.47 & 12.46 & 3.45 & Ovis & n/a \\
PB14 & -18.63 & 10.05 & 3.34 & Ovis & n/a \\
PB15 & -18.77 & 9.83 & 3.25 & Ovis & n/a \\
PB16 & -17.89 & 10.20 & 3.2 & Ovis & n/a \\
PB17 & -17.98 & 11.14 & 3.25 & Ovis & n/a \\
PB18 & -18.45 & 10.05 & 3.2 & Ovis & n/a \\
PB19 & -18.07 & 9.41 & 3.25 & Ovis & n/a \\
PB20 & -18.89 & 8.52 & 3.25 & Ovis & n/a \\
PB21 & -16.61 & 11.97 & 3.4 & Ovis & Ovis/Capra \\
PB22 & -16.69 & 10.78 & 3.25 & Ov &
\end{tabular}




\section{Çatalhöyük West}

\begin{tabular}{|c|c|c|c|c|c|}
\hline Lab no. & $\delta^{13} C$ & $\delta^{15} N$ & $C: N$ & Species & Element \\
\hline CW003 & -20.5 & 10.2 & 3.3 & Lepus & Ulna \\
\hline CW004 & -17.6 & 10.4 & 3.3 & Ovis/Capra & Humerus \\
\hline CW005 & -18.3 & 12.0 & 3.3 & Ovis/Capra & Humerus \\
\hline CW007 & -17.3 & 10.2 & 3.3 & Capra & Humerus \\
\hline CW008 & -18.6 & 9.3 & 3.3 & Ovis & Humerus \\
\hline CW009 & -17.9 & 10.5 & 3.3 & Ovis & Humerus \\
\hline CW010 & -19.1 & 9.3 & 3.3 & Ovis & Humerus \\
\hline CW011 & -19.1 & 8.7 & 3.3 & Ovis & Humerus \\
\hline CW012 & -16.2 & 11.0 & 3.4 & Ovis & Humerus \\
\hline CW014 & -17.3 & 11.1 & 3.3 & Ovis & Humerus \\
\hline CW015 & -18.3 & 8.7 & 3.3 & Ovis/Capra & Radius \\
\hline CW018 & -19.3 & 9.3 & 3.3 & Cervid & 2nd phalanx \\
\hline CW020 & -18.8 & 9.3 & 3.0 & Ovis & Humerus \\
\hline CW021 & -18.6 & 9.7 & 3.3 & Ovis & Humerus \\
\hline CW024 & -18.2 & 8.6 & 3.3 & Ovis/Capra & Metatarsal \\
\hline CW026 & -18.1 & 9.3 & 3.3 & Ovis & Humerus \\
\hline CW027 & -18.3 & 9.7 & 3.3 & Capra & Humerus \\
\hline CW028 & -17.6 & 10.6 & 3.3 & Ovis & Humerus \\
\hline CW029 & -19.8 & 8.6 & 3.2 & Capra & Metacarpal \\
\hline CW030 & -17.8 & 10.1 & 3.3 & Ovis/Capra & Radius \\
\hline CW035 & -17.8 & 10.8 & 3.2 & Lepus & Sacrum \\
\hline CW037 & -19.9 & 7.8 & 3.3 & Capra & Humerus \\
\hline CW038 & -17.1 & 9.8 & 3.3 & Capra & Metatarsal \\
\hline CW039 & -19.3 & 10.9 & 3.3 & Capra & Humerus \\
\hline CW040 & -17.4 & 9.8 & 3.4 & Ovis/Capra & Metacarpal \\
\hline
\end{tabular}




\section{Bibliography}

Andreeva, D.B., Zech, M., Glaser, B., Erbajeva, M.A., Chimitdorgieva, G.D., Ermakova, O.D., Zech, W. 2013: 'Stable isotope $\left(\delta^{13} \mathrm{C}, \delta^{15} \mathrm{~N}, \delta^{18} \mathrm{O}\right)$ record of soils in Buryatia, southern Siberia: implications for biogeochemical and paleoclimatic interpretations' Quaternary International 290-91: 82-94. https://doi.org/10.1016/j.quaint.2012.10.054

Ambrose, S.H. 1990: 'Preparation and characterization of bone and tooth collagen for isotopic analysis' Journal of Archaeological Science 17: 431-51. https://doi.org/10.1016/0305-4403(90)90007-R

— 1993: 'Isotopic analysis of paleodiets: methodological and interpretive considerations' in M.K. Sandford (ed.), Investigations of Ancient Human Tissue: Chemical Analysis in Anthropology. Langhorne, Gordon and Breach Science Publishers: 59-129

Ambrose, S.H., Norr, L. 1993: 'Experimental evidence for the relationship of the carbon isotope ratios of whole diet and dietary protein to those of bone collagen and carbonate' in J. Lambert, G. Grupe (eds), Prehistoric Human Bone: Archaeology at the Molecular Level. Berlin, Springer-Verlag: 1-37. https://doi.org/10.1007/978-3-662-02894-0_1

Amundson, R., Austin, A.T., Schuur, E.A.G., Yoo, K., Matzek, V. 2003: 'Global patterns of the isotopic composition of soil and plant nitrogen' Global Biogeochemical Cycles 17.1: 31-1-31-10

Arbuckle, B.S. 2008: 'Caprine exploitation at Erbaba Höyük: a Pottery Neolithic village in central Anatolia' in L. Gourichon, E. Vila (eds), Archaeology of Southwestern Asia and Adjacent Areas 8. Paris, Travaux de la Maison de 1'Orient: 345-65

Arbuckle, B.S., Atıc1, L. 2013: 'Initial diversity in sheep and goat management in Neolithic southwestern Asia' Levant 45.2: 219-35. https://doi.org/10.1179/0075891413Z.00000000026

Arbuckle, B.S., Kansa, S.W., Kansa, E., Orton, D., Çakırlar, C., Gourichon, L., Atıcı, L., Galik, A., Marciniak, A., Mulville, J., Buitenhuis, H., Carruthers, D., De Cupere, B., Demirergi, A., Frame, S., Helmer, D., Martin, L., Peters, J., Pöllath, N., Pawłowska, K., Russell, N., Twiss, K., Würtenberger, D. 2014: 'Data sharing reveals complexity in the westward spread of domestic animals across Neolithic Turkey’ PLOS ONE 9.6: e99845. https://doi.org/10.1371/journal.pone.0099845

Asouti, E., Fuller, D.Q. 2012: 'From foraging to farming in the southern Levant: the development of Epipalaeolithic and Pre-Pottery Neolithic plant management strategies' Vegetation History and Archaeobotany 21: 149-62. https://doi.org/10.1007/s00334-011-0332-0

Baird, D., Asouti, E., Astruc, L., Baysal, A., Baysal, E., Carruthers, D., Fairbairn, A., Kabukcu, C., Jenkins, E., Lorentz, K., Middleton, C., Pearson, J., Pirie, A. 2013: 'Juniper smoke, skulls and wolves' tails: the Epipalaeolithic of the Anatolian plateau in its south-west Asian context; insights from Pınarbaşı' Levant 45.2: 175-209. https://doi.org/10.1179/0075891413Z.00000000024

Baird, D., Fairbairn, A., Martin, L., Middleton, C. 2012: 'The Boncuklu Project: the origins of sedentism, cultivation and herding in central Anatolia' in M. Özdoğan, N. Başgelen, P. Kuniholm (eds), The Neolithic in Turkey 3: Central Turkey. Istanbul, Arkeoloji ve Sanat Yayınları: 219-44

Bar-Yosef, O., Meadow, R.H. 1995: 'The origins of agriculture in the Near East' in T.D. Price, A.B. Gebauer (eds), Last Hunters-First Farmers: New Perspectives on the Prehistoric Transition to Agriculture. Santa Fe, School of American Research Press: 39-94

Baruch, U., Bottema, S. 1999: 'A new pollen diagram from Lake Hula: vegetational climatic, and anthropogenic implications' in H. Kawanabe, G.W. Coulter, A.C. Roosevelt (eds), Ancient Lakes: Their Cultural and Biological Diversity. Belgium, Kenobe: $75-86$

Bayliss, A., Farid, S., Higham, T. 2014: 'Time will tell: practicing Bayesian chronological modeling on the East Mound' in I. Hodder (ed.), Çatalhöyük Excavations: The 2000-2008 Seasons. Los Angeles/London, Cotsen Institute of Archaeology/British Institute at Ankara: 53-90

Bellwood, P. 2009: 'The dispersals of established food-producing populations' Current Anthropology 50.5: 621-26. https://doi.org/10.1086/605112

Bender, B. 1978: 'Gatherer-hunter to farmer: a social perspective' World Archaeology 10: $204-22$. https://doi.org/10.1080/00438243.1978.9979731

Bettinger, R., Barton, L., Richerson, P.J., Boyd, R., Wang, R.H., Choi, W. 2007: 'The transition to agriculture in northwestern China' in D.B. Madsen, F. Chen, X. Gao (eds), Late Quaternary Climate Change and Human Adaptation in Arid China. Amsterdam, Elsevier: 83-101

Bettinger, R., Richerson, P., Boyd, R. 2009: 'Rethinking the origins of agriculture: constraints on the development of agriculture' Current Anthropology 50.5: 627-31. https://doi.org/10.1086/605359

Boessneck, J. 1969: 'Osteological differences between sheep (Ovis aries Linneé) and goat (Capra hircus Linné)' in D.R. Brothwell, E.S. Higgs (eds), Science in Archaeology: A Comprehensive Survey of Progress and Research. London, Thames \& Hudson: 331-58 
Bogaard, A., Charles, M., Livarda, A., Ergun, M., Filipovic, D., Jones, G. 2013: 'The archaeobotany of mid-later Neolithic Çatalhöyük' in I. Hodder (ed.), Humans and Landscapes of Çatalhöyük: Reports from the 2000-2008 Seasons. Los Angeles/London, Cotsen Institute of Archaeology/British Institute at Ankara: 93-128

Bogaard, A., Heaton, T.H.E., Poulton, P., Merbach, I. 2007: 'The impact of manuring on nitrogen isotope ratios in cereals: archaeological implications for reconstruction of diet and crop management practices' Journal of Archaeological Science 34: 335-43. https://doi.org/10.1016/j.jas.2006.04.009

Bökönyi, S. 1969: ‘Archaeological problems and methods of recognizing animal domestication' in P.J. Ucko, G.W. Dimbleby (eds), The Domestication and Exploitation of Plants and Animals. London, Duckworth: 219-29

Bol, R., Eriksen, J., Smith, P., Garnett, M.H., Coleman, K., Christensen, B.T. 2005: 'The natural abundance of ${ }_{13}$ C, ${ }_{15}$ N, ${ }_{34} \mathrm{~S}$ and ${ }_{14} \mathrm{C}$ in archived (1923-2000) plant and soil samples from the Askov long-term experiments on animal manure and mineral fertilizer' Rapid Communications in Mass Spectrometry 19: 3216-26. https://doi.org/10.1002/rcm.2156

Bowman, W.D., Hubick, K.T., von Caemmerer, S., Farquhar, G.D. 1989: 'Short-term changes in leaf carbon isotope discrimination in salt- and water-stressed $\mathrm{C}_{4}$ grasses' Plant Physiology 90: 162-66. https://doi.org/10.1104/pp.90.1.162

Boyd, B. 2005: 'Transforming food practices in the later Epipaleolithic and Pre-Pottery Neolithic Levant' in J. Clarke (ed.), Archaeological Prespectives on the Transmission and Transformation of Culture in the Eastern Mediterranean. Oxford, Oxbow Books: 106-12

Brenner, D.L., Amundson, R., Baisden, W.T., Kendall, C., Harden, J. 2001: 'Soil N and ${ }^{15} \mathrm{~N}$ variation with time in a California grassland ecosystem' Geochimica et Cosmochimica Acta 65.22: 4171-86. https://doi.org/10.1016/S00167037(01)00699-8

Broadmeadow, M.S.J., Griffiths, H., Maxwell, C., Borland, A.M. 1992: 'The carbon isotope ratio of plant organic material reflects temporal and spatial variations in $\mathrm{CO}_{2}$ within tropical forest formations in Trinidad' Oecologia 89: 435-41. https://doi.org/10.1007/BF00317423

Brown, T.A., Nelson, D.E., Vogel, J.S., Sothon, J.R. 1988: 'Improved collagen extraction by modified Longin method' Radiocarbon 30: 171-77. https://doi.org/10.1017/S0033822200044118

Bruford, M., Townsend, S.J. 2006: 'Mitochondrial DNA diversity in modern sheep' in M.A. Zeder, D.G. Bradley, E. Emshwiller, B.D. Smith (eds), Documenting Domestication: New Genetic and Archaeological Paradigms. Berkeley, University of California Press: 306-16

Buitenhuis, H. 1997: ‘Asıklı Höyük: a “protodomestication” site’ Anthropozoologica 25-26: 655-62

Cauvin, J. 2000: The Birth of the Gods and the Origins of Agriculture. Cambridge, Cambridge University Press

Cerling, T.E., Hart, J.A., Hart, T.B. 2004: 'Stable isotope ecology in the Ituri Forest' Oecologia 138: 5-12. https://doi.org/10.1007/s00442-003-1375-4

Cheng, H.H., Bremmer, J.M., Edwards, A.P. 1964: 'Variations of nitrogen-15 abundance in soils' Science 146: 1574 75. https://doi.org/10.1126/science.146.3651.1574

Childe, V.G. 1928: The Most Ancient Near East: The Oriental Prelude to European Prehistory. London, Kegan Paul

- 1936: Man Makes Himself. London, Watts

- 1942: What Happened in History. Harmondsworth, Penguin

Choi, W.-J., Lee, S.-M., Ro, H.-M., Kim, K.-C., Yoo, S.-H. 2002: 'Natural ${ }^{15} \mathrm{~N}$ abundances of maize and soil amended with urea and composted pig manure' Plant and Soil 245: 223-32. https://doi.org/10.1023/A:1020475017254

Cohen, M.N. 1977: The Food Crisis in Prehistory: Overpopulation and the Origins of Agriculture. New Haven, Yale University Press

— 2009: 'Rethinking the origins of agriculture' Current Anthropology 50.5: 591-95. https://doi.org/10.1086/603548

Conolly, J., Colledge, S., Dobney, K., Vigne, J.-D., Peters, J., Stopp, B., Manning, K., Shennan, S. 2011: 'Meta-analysis of zooarchaeological data from SW Asia and SE Europe provides insight into the origins and spread of animal husbandry' Journal of Archaeological Science 38: 538-45. https://doi.org/10.1016/j.jas.2010.10.008

Delwiche, C.C., Steyn, P.L. 1970: 'Nitrogen isotope fractionation in soils and microbial reactions' Environmental Science and Technology 4: 929-35. https://doi.org/10.1021/es60046a004

Demirci, S., Baştanlar, E.K., Dağtaş, N.D., Pişkin, E., Engin, A., Özer, F., Yüncü, E., Doğan, Ş.A., Togan, İ. 2013: 'Mitochondrial DNA diversity of modern, ancient and wild sheep (Ovis gmelinii anatolica) from Turkey: new insights on the evolutionary history of sheep' PLoS One 8.12: e81952. https://doi.org/10.1371/journal.pone.0081952

DeNiro, M.J. 1985: 'Post-mortem preservation and alteration of in-vivo bone collagen isotope ratios in relation to paleodietary reconstruction' Nature 317: 806-09. https://doi.org/10.1038/317806a0

DeNiro, M.J., Epstein, S. 1978: 'Influence of diet on the distribution of carbon isotopes in animals' Geochimica et Cosmochimica Acta 42: 495-506. https://doi.org/10.1016/0016-7037(78)90199-0 
- 1981: 'Influence of diet on the distribution of nitrogen isotopes in animals' Geochimica et Cosmochimica 45: 34151. https://doi.org/10.1016/0016-7037(81)90244-1

Downton, W.J.S., Grant, W.J.R., Robinson, S.P. 1985: 'Photosynthetic and stomatal response of spinach leaves to salt stress' Plant Physiology 77: 85-88. https://doi.org/10.1104/pp.78.1.85

Ducos, P. 1978: “Domestication” defined and methodological approaches to its recognition in faunal assemblages' in R.H. Meadow, M. Zeder (eds), Approaches to Faunal Analysis in the Middle East 2. Cambridge MA, Peabody Museum Press: 53-56

Ehleringer, J.R., Cooper, T.A. 1988: 'Correlations between carbon isotope ratio and microhabitat in desert plants' Oecologia 76: 562-66. https://doi.org/10.1007/BF00397870

Fairbairn, A., Jenkins, E., Baird, D., Jacobsen, G. 2014: '9th millennium plant subsistence in the central Anatolian highlands: new evidence from Pınarbaşı, Karaman province, central Anatolia’ Journal of Archaeological Science 41: 801-12. https://doi.org/10.1016/j.jas.2013.09.024

Fairbairn, A., Near, J., Martinoli, D. 2005: 'Macrobotanical investigations of the North, South and KOPAL areas at Çatalhöyük' in I. Hodder (ed.), Inhabiting Çatalhöyük: Reports from the 1995-1999 Seasons. Cambridge/London, McDonald Institute for Archaeological Research/British Institute at Ankara: 137-201

Flannery, K.V. 1969: 'Origins and ecological effects of early domestication in Iran and the Near East' in P.J. Ucko, G.W. Dimbleby (eds), The Domestication and Exploitation of Plants and Animals. London, Duckworth: 73-100

French, D., Hillman, G.C., Payne, S., Payne, R.J. 1972: ‘Excavations at Can Hasan III 1969-1970’ in E.S. Higgs (ed.), Papers in Economic Prehistory. Cambridge, Cambridge University Press: 181-90

Gerbault, P., Powell, A., Thomas, M.G. 2012: 'Evaluating demographic models for goat domestication using mtDNA sequences' Anthropozoologica 47: 64-76. https://doi.org/10.5252/az2012n2a5

Gremillion, K.J., Piperno, D.R. 2009: 'Human behavioural ecology, phenotypic (developmental) plasticity, and agricultural origins: insights from the emerging evolutionary synthesis' Current Anthropology 50.5: 615-19. https://doi.org/10.1086/605360

Grossman, L., Belfer-Cohen, A. 2002: 'Zooming onto the "Younger Dryas"' in R.T.J. Cappers, S. Bottema (eds), The Dawn of Farming in the Near East: Studies in Early Near Eastern Production, Subsistence, and Environment 6. Berlin, Ex Oriente: 49-54

Handley, L.L., Austin, A.T, Robinson, D., Scrimgeour, C.M., Raven, J.A., Heaton, T.H.E., Schmidt, S., Stewart, G.R. 1999: 'The N-15 natural abundance (delta N-15) of ecosystem samples reflects measures of water availability' Australian Journal of Plant Physiology 26.2: 185-99. https://doi.org/10.1071/PP98146

Harris, D.R. 2003: 'Climatic change and the beginnings of agriculture: the case of the Younger Dryas' in L. Rothschild, A. Lister (eds), Evolution on Planet Earth: The Impact of the Physical Environment. London, Elsevier: 379-94. https://doi.org/10.1016/B978-012598655-7/50047-1

Hayden, B. 1990: 'Nimrods, piscators, pluckers, and planters: the emergence of food production' Journal of Anthropological Archaeology 9: 31-69. https://doi.org/10.1016/0278-4165(90)90005-X

- 1992: 'Models of domestication' in T.D. Price, A.B. Gebauer (eds), Transitions to Agriculture in Prehistory. Madison, Prehistory Press: 11-19

- 1995: 'A new overview of domestication' in T.D Price, A.B. Gebauer (eds), Last Hunters-First Farmers: New Perspectives on the Prehistoric Transition to Agriculture. Santa Fe, School of American Research Press: 273-99

- 1996: 'Feasting in prehistoric and traditional societies' in P. Wiessner, W. Schiefenhovel (eds), Food and the Status Quest: An Interdisciplinary Perspective. Oxford, Berghahn: 127-47

- 2001: 'Fabulous feasts: a prolegomenon to the importance of feasting' in M. Dietler, B. Hayden (eds), Feasts: Archaeological and Ethnographic Perspectives on Food, Politics, and Power. Washington DC, Smithsonian Institution Press: 23-64

- 2003: 'Were luxury foods the first domesticates? Ethnoarchaeological perspectives from southeast Asia' World Archaeology 34: 458-69. https://doi.org/10.1080/0043824021000026459a

- 2009: 'The proof is in the pudding: feasting and the origins of domestication' Current Anthropology 50.5: 597-601. https://doi.org/10.1086/605110

Heaton, T.H.E. 1987: 'The ${ }^{15} \mathrm{~N} /{ }^{14} \mathrm{~N}$ ratios of plants in South Africa and Namibia: relationship to climate and coastal/saline environments' Oecologia 74: 236-46. https://doi.org/10.1007/BF00379365

- 1999: 'Spatial, species and temporal variations in the ${ }^{13} \mathrm{C} /{ }^{12} \mathrm{C}$ ratios of $\mathrm{C}_{3}$ plants: implications for palaeodiet studies' Journal of Archaeological Science 26: 637-49. https://doi.org/10.1006/jasc.1998.0381

Hedges, R.E.M., Reynard, L.M. 2007: 'Nitrogen isotopes and the trophic level of humans in archaeology' Journal of 
Archaeological Science 34: 1240-51. https://doi.org/10.1016/j.jas.2006.10.015

Hemming, D.L., Switsur, V.R., Waterhouse, J.S., Heaton, T.H.E., Carter, A.H.C. 1998: 'Climate and stable isotope composition of tree ring cellulose: an intercomparison of three tree species' Tellus 50B: 25-33. https://doi.org/10.3402/tellusb.v50i1.16019

Henry, D.O. 2002: 'Models of agricultural origins and proxy measures of prehistoric demographics' in R.T.J. Cappers, S. Bottema (eds), The Dawn of Farming in the Near East: Studies in Early Near Eastern Production, Subsistence, and Environment 6. Berlin, Ex Oriente: 15-26

Henton, E. 2013: 'Oxygen stable isotope and dental microwear evidence of herding practices at Çatalhöyük' in I. Hodder (ed.), Humans and Landscapes of Çatalhöyük: Reports from the 2000-2008 Seasons. Los Angeles/London, Cotsen Institute of Archaeology/British Institute at Ankara: 299-316

Hole, F. 1996: 'The context of caprine domestication in the Zagros region' in D.R. Harris (ed.), The Origins and Spread of Agriculture and Pastoralism in Eurasia. London, University College London Press: 263-81

Hole, F., Flannery, K.V., Neely, J.A. 1969: Prehistory and Human Ecology on the Deh Luran Plain: An Early Village Sequence from Khuzistan, Iran. Ann Arbor, Museum of Anthropology, University of Michigan

Horwitz, L.K., Tchernov, E., Ducos, P., Becker, C., von den Driesch, A., Martin, L., Garrard, A. 1999: 'Animal domestication in the southern Levant' Paléorient 25.2: 63-80. https://doi.org/10.3406/paleo.1999.4687

Ingold, T. 1980: Hunters, Pastoralists, and Ranchers: Reindeer Economies and their Transformation. Cambridge, Cambridge University Press. https://doi.org/10.1017/CBO9780511558047

Johnson, D.A., Asay, K.H., Tieszen, L.L., Ehlcringer, J., Jefferson, P. 1989: 'Carbon isotope discrimination: a possible selection criterion for improving range grass production in water-limited environments' Crop Science 30: 338-43. https://doi.org/10.2135/cropsci1990.0011183X003000020019x

Jones, M.D., Leng, M.J., Roberts, N., Türkeş, M., Moyeed, R. 2005: 'A coupled calibration and modelling approach to the understanding of dry-land lake oxygen isotope records' Journal of Paleolimnology 34: 391-411. https://doi.org/10.1007/s10933-005-6743-0

Jones, M.D., Roberts, C.N. 2008: 'Interpreting lake isotope records of Holocene environmental change in the eastern Mediterranean' Quaternary International 181.1: 32-38. https://doi.org/10.1016/j.quaint.2007.01.012

Jones, M.D., Roberts, C.N., Leng M.J. 2007: 'Quantifying climatic change through the last glacial-interglacial transition based on lake isotope palaeohydrology from central Turkey' Quaternary Research 67: 463-73. https://doi.org/10.1016/j.yqres.2007.01.004

Koch, G.W., Sillet, S.C., Jennings, G.M., Davis, S.D. 2004: 'The limits to tree height' Nature 428: 851-54. https://doi.org/10.1038/nature02417

Körner, C.H., Farquhar, G.D., Roksandic, S. 1988: 'A global survey of carbon isotope discrimination in plants from high altitude’ Oecologia 74: 623-32. https://doi.org/10.1007/BF00380063

Körner, C.H., Farquhar, G.D., Wong, S.C. 1991: 'Carbon isotope discrimination by plants follows latitudinal and altitudinal trends' Oecologia 88: 30-40. https://doi.org/10.1007/BF00328400

Lambert, P.M. 2009: 'Health versus fitness: competing themes in the origins and spread of agriculture?' Current Anthropology 50.5: 603-08. https://doi.org/10.1086/605354

Lipp, J., Trimborn, P., Fritz, P., Moser, H., Becker, B., Frenzel, B. 1991: ‘Stable isotopes in tree ring cellulose and climate change' Tellus 43B: 322-30. https://doi.org/10.3402/tellusb.v43i3.15280

Longin, R. 1971: 'New method of collagen extraction for radiocarbon dating' Nature 230: 241-42. https://doi.org/10.1038/230241a0

Luikart, G., Fernández, H., Mashkour, M., England, P.R., Taberlet, P. 2006: 'Origins and diffusion of domestic goats inferred from DNA markers' in M.A. Zeder, D.G. Bradley, E. Emshwiller, B.D. Smith (eds), Documenting Domestication: New Genetic and Archaeological Paradigms. Berkeley, University of California Press: 294-305

Maricle, B.R., Lee, R.W. 2006: 'Effects of environmental salinity on carbon isotope discrimination and stomatal conductance in Spartina grasses' Marine Ecology Progress Series 313: 305-10. https://doi.org/10.3354/meps313305

Martin, L. 1999: 'Mammal remains from the eastern Jordanian Neolithic, and the nature of caprine herding in the steppe' Paléorient 25.2: 87-104. https://doi.org/10.3406/paleo.1999.4689

Martinelli, L.A., Victoria, R.L., de Camargo, P.B., de Cassia Piccolo, M., Mertes, L., Richey, J.E., Devol, A.H., Fosberg, B.R. 2003: 'Inland variability of carbon-nitrogen concentrations and $\delta^{13} \mathrm{C}$ in Amazon floodplain (várzea) vegetation and sediment' Hydrological Processes 17: 1419-30. https://doi.org/10.1002/hyp.1293

Matthews, R., Matthews, W., Mohamadifar, Y. (eds) 2013: The Earliest Neolithic of Iran: 2008 Excavations at Sheikh-e Abad and Jani. Oxford, British Institute of Persian Studies/Oxbow Books 
Matthews, R., Mohammadifar, Y., Matthews, W., Motarjem, A. 2010: 'Investigating the Early Neolithic of western Iran: the Central Zagros Archaeological Project (CZAP)' Antiquity. http://antiquity.ac.uk/projgall/matthews323/

Meadow, R. 1989: 'Osteological evidence for the process of animal domestication' in J. Clutton-Brock (ed.), The Walking Larder: Patterns of Domestication, Pastoralism, and Predation. London, Unwin Hyman: 80-90

Meadows, J.R.S., Cemal, I., Karaca, O., Gootwine, E., Kijas, J.W. 2007: 'Five ovine mitochondrial lineages identified from sheep breeds of the Near East' Genetics 175.3: 1371-79. https://doi.org/10.1534/genetics.106.068353

Medina, E., Minchin, P. 1980: ‘Stratification of $\delta^{13} \mathrm{C}$ values of leaves in Amazonian rain forests' Oecologia 45: 377-78. https://doi.org/10.1007/BF00540209

Middleton, C. 2014: The Nature of the Earliest Animal Management in Central Anatolia 13,000-5,000 cal. BC: A Stable Isotope Study. $\mathrm{PhD}$ thesis, University of Liverpool

Mizutani, H., Wada, E. 1988: 'Nitrogen and carbon isotope ratios in seabird rookeries and their ecological implications' Ecology 69.2: 340-49. https://doi.org/10.2307/1940432

Moore, A.T.M., Hillman, G. 1992: 'The Pleistocene to Holocene transition and human economy in southwest Asia: the impact of the Younger Dryas' American Antiquity 57: 482-94. https://doi.org/10.2307/280936

Moore, A.T.M., Hillman, G., Legge, A. 2000: Village on the Euphrates: From Foraging to Farming at Abu Hureyra. Oxford, Oxford University Press

Munro, N.D. 2004: 'Zooarchaeological measures of hunting pressure and occupation intensity in the Natufian: implications for agricultural origins' Current Anthropology 45.S4: S5-34. https://doi.org/10.1086/422084

Munson, P.J. 2000: 'Age-correlated differential destruction of bone and its effect on archaeological mortality profiles of domestic sheep and goats' Journal of Archaeological Science 27: 391-407. https://doi.org/10.1006/jasc.1999.0463

Naderi, S., Rezaei, H.-R., Pompanon, R., Blum, M.G., Naghash, H.R., Balkiz, O., Mashkour, M., Gaggiotti, O.E., Ajmone-Marsan, P., Vigne, J.-D., Taberiet, P. 2008: 'The goat domestication process inferred from large-scale mitochondrial DNA analysis of wild and domestic individuals' Proceedings of the National Academy of Sciences USA 105.46: 17659-64. https://doi.org/10.1073/pnas.0804782105

Naderi, S., Rezaei, H.-R., Taberlet, P., Zundel, S., Rafat, S.-A., Naghash, H.-R., El-Barody, M.A.A., Ertuğrul, O., Pompanon, F. 2007: 'Large-scale mitochondrial DNA analysis of the domestic goat reveals six haplogroups with high diversity’ PLoS ONE 2.10: e1012. https://doi.org/10.1371/journal.pone.0001012

Nardoto, G.B., Ometto, J.P.H.B., Ehleringer, J.R., Higuchi, N., da Cunha Bustamante, M.M., Martinelli, L.A. 2008: 'Understanding the influences of spatial patterns on $\mathrm{N}$ availability within the Brazilian Amazon Forest' Ecosystems 11: 1234-46. https://doi.org/10.1007/s10021-008-9189-1

Neales, T.F., Fraser, M.S., Roksandic, Z. 1983: 'Carbon isotope composition of the halophyte Disphyma clavellatum (Haw.) Chinnock (Aizoaceae), as affected by salinity’ Australian Journal of Plant Physiology 10: 437-44. https://doi.org/10.1071/PP9830437

O'Leary, M.H. 1981: 'Carbon isotope fractionation in plants' Phytochemistry 20: 553-67. https://doi.org/10.1016/00319422(81)85134-5

- 1988: 'Carbon isotopes in photosynthesis' BioScience 38.5: 328-35. https://doi.org/10.2307/1310735

Özdoğan, M. 2011: 'Archaeological evidence on the westward expansion of farming communities from eastern Anatolia to the Aegean and the Balkans' Current Anthropology 52: S415-30. https://doi.org/10.1086/658895

Pearson, J.A. 2004: Ancient Diet in Neolithic Anatolia: Isotopic Analyses of Biological Remains and their Archaeological Implications. $\mathrm{PhD}$ thesis, University of Oxford

- 2013: 'Human and animal diets as evidenced by stable carbon and nitrogen isotope analysis' in I. Hodder (ed.), Humans and Landscapes of Çatalhöyük: Reports from the 2000-2008 Seasons. Los Angeles/London, Cotsen Institute of Archaeology/British Institute at Ankara: 271-98

Pearson, J.A., Buitenhuis, H., Hedges, R.E.M., Martin, L., Russell, N., Twiss, K.C. 2007: 'New light on early caprine herding strategies from isotope analysis: a case study from Neolithic Anatolia' Journal of Archaeological Science 34: 2170-79. https://doi.org/10.1016/j.jas.2007.09.001

Perkins, D. 1964: 'Prehistoric fauna from Shanidar, Iraq' Science 144: 1565-66. https://doi.org/10.1126/science.144.3626.1565

Peters, J., Helmer, D., von den Driesch, A., Sana Segui, M. 1999: 'Early animal husbandry in the northern Levant' Paléorient 25.2: 27-48. https://doi.org/10.3406/paleo.1999.4685

Peters, J., von den Dreisch, A., Helmer, D. 2005: 'The upper Euphrates-Tigris basin: cradle of agro-pastoralism?' in J.-D. Vigne, J. Peters, D. Helmer (eds), The First Steps of Animal Domestication: New Archaeological Approaches. Oxford, Oxbow: 96-124 
Post, D.M. 2002: 'Using stable isotopes to estimate trophic position; models, methods, and assumptions' Ecology 83.3: 703-18. https://doi.org/10.1890/0012-9658(2002)083[0703:USITET]2.0.CO;2

Price, T.D., Bar-Yosef, O. 2011: 'The origins of agriculture: new data, new ideas (an introduction to Supplement 4)' Current Anthropology 52.S4: S163-74. https://doi.org/10.1086/659964

Redding, R.W. 2005: 'Breaking the mould: a consideration of variation in the evolution of animal domestication' in J.-D. Vigne, J. Peters, D. Helmer (eds), The First Steps of Animal Domestication: New Archaeological Approaches. Oxford, Oxbow: 41-48

Richards, M.P., Hedges, R.E.M. 1999: 'Stable isotope evidence for similarities in the types of marine foods used by Late Mesolithic humans at sites along the Atlantic coast of Europe' Journal of Archaeological Science 26: 717-22. https://doi.org/10.1006/jasc.1998.0387

Richerson, P.J., Boyd, R., Bettinger, R.L. 2001: 'Was agriculture impossible during the Pleistocene but mandatory during the Holocene? A climate change hypothesis' American Antiquity 66.3: 387-411. https://doi.org/10.2307/2694241

Roberts, N., Reed, J.M., Leng, M.J., Kuzucuoğlu, C., Fontugne, M., Bertaux, J., Woldring, H., Bottema, S., Black, S., Hunt, E., Karabiyıkoğlu, M. 2001: 'The tempo of Holocene climatic change in the eastern Mediterranean region: new high-resolution crater-lake sediment data from central Turkey' The Holocene 11.6: 721-36. https://doi.org/10.1191/09596830195744

Rosen, A.M. 2005: 'Phytolith indicators of plant and land use at Çatalhöyük' in I. Hodder (ed.), Çatalhöyük Perspectives: Reports from the 1995-99 Seasons. Cambridge/London, McDonald Institute for Archaeological Research/British Institute at Ankara: 203-12

Russell, N. 2012: Social Zooarchaeology: Humans and Animals in Prehistory. New York, Cambridge University Press Russell, N., Martin, L. 2005: 'Çatalhöyük mammal remains' in I. Hodder (ed.), Inhabiting Çatalhöyük: Reports from the 199599 Seasons. Cambridge/London, McDonald Institute for Archaeological Research/British Institute at Ankara: 33-98

Sage, R.F., Wedin, D.A., Li, M. 1999: 'The biogeography of $\mathrm{C}_{4}$ photosynthesis: patterns and controlling factors' in R.F. Sage, R.K. Monson (eds), $C_{4}$ Plant Biology. New York, Academic Press: 313-73. https://doi.org/10.1016/B978012614440-6/50011-2

Sandquist, D.R., Ehleringer, J.R. 1995: 'Carbon isotope discrimination in the $\mathrm{C}_{4}$ shrub Atriplex confertifolia along a salinity gradient' Great Basin Naturalist 55: 135-41

Senbayram, M., Dixon, L., Goulding, K.W.T., Bol, R. 2008: 'Long-term influence of manure and mineral nitrogen applications on plant and soil ${ }^{15} \mathrm{~N}$ and ${ }^{13} \mathrm{C}$ values from the Broadbalk Wheat Experiment' Rapid Communications in Mass Spectrometry 22: 1735-40. https://doi.org/10.1002/rcm.3548

Shearer, G., Kohl, D.H., Chien, S.-H. 1978: 'The nitrogen-15 abundance in a wide variety of soils' Soil Science Society of America Journal 42.6: 899-902. https://doi.org/10.2136/sssaj1978.03615995004200060013x

Stiner, M.C., Buitenhuis, H., Duruc, G., Kuhna, S.L., Mentzera, S.M., Munroe, N.D., Pöllathf, N., Quadeg, J., Tsartsidouh, G., Özbaşaran, M. 2014: 'A forager-herder trade-off, from broad-spectrum hunting to sheep management at Aşıkl1 Höyük' Proceedings of the National Academy of Sciences USA 111.23: 8404-09. https://doi.org/10.1073/pnas.1322723111

Tieszen, L.L. 1991: 'Natural variations in the carbon isotope values of plants: implications for archaeology, ecology, and paleoecology' Journal of Archaeological Science 18: 227-48. https://doi.org/10.1016/0305-4403(91)90063-U

Tieszen, L.L., Johnson, D.A., Caldwell, M.M. 1974: 'A portable system for the measurement of photosynthesis using 14-carbon dioxide' Photosynthetica 8: 151-60

van der Merwe, N.J., Medina, E. 1989: 'Photosynthesis and ${ }^{13} \mathrm{C} /{ }^{12} \mathrm{C}$ ratios in Amazonian rainforests' Geochimica et Cosmochimica Acta 53: 1091-94. https://doi.org/10.1016/0016-7037(89)90213-5

van Groenigen, J.-W., van Kessel, C. 2002: 'Salinity-induced patterns of natural abundance carbon-13 and nitrogen-15 in plant and soil' Soil Science Society of America Journal 66: 489-98. https://doi.org/10.2136/sssaj2002.4890

van Klinken, G.J. 1999: 'Bone collagen quality indicators for palaeodietary and radiocarbon measurements' Journal of Archaeological Science 26: 687-95. https://doi.org/10.1006/jasc.1998.0385

van Klinken, G.J., van der Plicht, H., Hedges, R.E.M. 1994: 'Bone ${ }^{13} \mathrm{C} /{ }^{12} \mathrm{C}$ ratios reflect (palaeo-) climatic variations' Geophysical Research Letters 21: 445-48. https://doi.org/10.1029/94GL00177

Vigne, J.-D. 2011: 'The origins of animal domestication and husbandry: a major change in the history of humanity and the biosphere' Comptes rendus Biologies 334: 171-81. https://doi.org/10.1016/j.crvi.2010.12.009

Vigne, J.-D., Carriere, I., Guilaine, J. 2003: 'Unstable status of early domestic ungulates in the Near East: the example of Shillourokambos (Cyprus, IX-VIIIth millennia cal. B.C.)' Bulletin de Correspondance Hellénique Supplement 43: 239-52 
Vigne, J.-D., Helmer, D. 2007: 'Was milk a "secondary product" in the Old World Neolithisation process? Its role in the domestication of cattle, sheep and goats' Anthropozoologica 42: 9-40

Wang, L., D'Odorico, P., Ries, L., Macko, S.A. 2010: 'Patterns and implications of plant-soil $\delta^{13} \mathrm{C}$ and $\delta^{15} \mathrm{~N}$ values in African savanna ecosystems' Quaternary Research 73: 77-83. https://doi.org/10.1016/j.yqres.2008.11.004

Wasse, A. 2001: 'The wild goats of Lebanon: evidence for early domestication?' Levant 33: 21-33. https://doi.org/10.1179/lev.2001.33.1.21

- 2002: 'Final results of an analysis of the sheep and goat bones from Ain Ghazal, Jordan' Levant 34: 59-82. https://doi.org/10.1179/lev.2002.34.1.59

Wick, L., Lemcke, G., Sturm, M. 2003: 'Evidence of Late Glacial and Holocene climatic change and human impact in eastern Anatolia: high-resolution pollen, charcoal, isotopic and geochemical records from the laminated sediments of Lake Van, Turkey' Holocene 13: 665-75. https://doi.org/10.1191/0959683603hl653rp

Winterhalder, B., Kennett, D. 2009: 'Four neglected concepts with a role to play in explaining the origins of agriculture' Current Anthropology 50.5: 645-48. https://doi.org/10.1086/605355

Zeder, M.A. 2005: 'A view from the Zagros: new perspectives on livestock domestication in the Fertile Crescent' in J.-D. Vigne, J. Peters, D. Helmer (eds), The First Steps of Animal Domestication: New Archaeological Approaches. Oxford, Oxbow: $125-46$

- 2006: 'Archaeological approaches to documenting animal domestication' in M.A. Zeder, D.G. Bradley, E. Emshwiller, B.D. Smith (eds), Documenting Domestication: New Genetic and Archaeological Paradigms. Berkeley, University of California Press: $171-80$

- 2008: 'Domestication and early agriculture in the Mediterranean basin: origins, diffusion, and impact' Proceedings of the National Academy of Sciences USA 105.33: 11597-604. https://doi.org/10.1073/pnas.0801317105

— 2011: 'The origins of agriculture in the Near East' Current Anthropology 52.S4: S221-35.

https://doi.org/10.1086/659307 